\section{OPEN ACCESS}

Edited by:

Pankaj Kumar Arora,

Yeungnam University, South Korea

Reviewed by:

Vijai Kumar Gupta,

National University of Ireland, Galway,

Ireland

Pradeep Kumar

Ben Gurion University of the Negev,

Israel

*Correspondence:

Sarvajeet S. Gill

ssgill14@yahoo.co.in;

Narendra Tuteja

ntuteja@amity.edu

Specialty section:

This article was submitted to

Microbiotechnology, Ecotoxicology

and Bioremediation,

a section of the journal

Frontiers in Microbiology

Received: 06 January 2016

Accepted: 03 February 2016

Published: 22 March 2016

Citation:

Gill SS, Gill R, Trivedi DK, Anjum NA, Sharma KK, Ansari MW, Ansari AA, Johri AK, Prasad R, Pereira E,

Varma A and Tuteja N (2016) Piriformospora indica: Potential and Significance in Plant Stress

Tolerance. Front. Microbiol. 7:332. doi: 10.3389/fmicb.2016.00332

\title{
Piriformospora indica: Potential and Significance in Plant Stress Tolerance
}

\author{
Sarvajeet S. Gill1*, Ritu Gill1, Dipesh K. Trivedi², Naser A. Anjum³, Krishna K. Sharma4, \\ Mohammed W. Ansari' ${ }^{2}$, Abid A. Ansari ${ }^{5}$, Atul K. Johri6, Ram Prasad ${ }^{7}$, Eduarda Pereira ${ }^{3}$, \\ Ajit Varma ${ }^{7}$ and Narendra Tuteja ${ }^{7 *}$
}

\begin{abstract}
'Stress Physiology and Molecular Biology Laboratory, Centre for Biotechnology, Maharshi Dayanand University, Rohtak, India, ${ }^{2}$ Plant Molecular Biology Group, International Centre for Genetic Engineering and Biotechnology, New Delhi, India, ${ }^{3}$ Centre for Environmental and Marine Studies and Department of Chemistry, University of Aveiro, Aveiro, Portugal,

${ }^{4}$ Department of Microbiology, Maharshi Dayanand University, Rohtak, India, ${ }^{5}$ Department of Biology, University of Tabuk, Tabuk, Saudi Arabia, ${ }^{6}$ School of Life Sciences, Jawaharlal Nehru University, New Delhi, India, ${ }^{7}$ Amity Institute of Microbial Technology, Amity University, Noida, India
\end{abstract}

Owing to its exceptional ability to efficiently promote plant growth, protection and stress tolerance, a mycorrhiza like endophytic Agaricomycetes fungus Piriformospora indica has received a great attention over the last few decades. $P$. indica is an axenically cultiviable fungus which exhibits its versatility for colonizing/hosting a broad range of plant species through directly manipulating plant hormone-signaling pathway during the course of mutualism. $P$. indica-root colonization leads to a better plant performance in all respect, including enhanced root proliferation by indole-3-acetic acid production which in turn results into better nutrient-acquisition and subsequently to improved crop growth and productivity. Additionally, P. indica can induce both local and systemic resistance to fungal and viral plant diseases through signal transduction. $P$. indicamediated stimulation in antioxidant defense system components and expressing stressrelated genes can confer crop/plant stress tolerance. Therefore, $P$. indica can biotize micropropagated plantlets and also help these plants to overcome transplantation shock. Nevertheless, it can also be involved in a more complex symbiotic relationship, such as tripartite symbiosis and can enhance population dynamic of plant growth promoting rhizobacteria. In brief, $P$. indica can be utilized as a plant promoter, biofertilizer, bioprotector, bioregulator, and biotization agent. The outcome of the recent literature appraised herein will help us to understand the physiological and molecular bases of mechanisms underlying $P$. indica-crop plant mutual relationship. Together, the discussion will be functional to comprehend the usefulness of crop plant- $P$. indica association in both achieving new insights into crop protection/improvement as well as in sustainable agriculture production.

Keywords: Piriformospora indica, colonization potential, $\mathrm{Ca}^{2+}$ signaling, crop improvement, plant stress tolerance

\section{INTRODUCTION}

In natural ecosystems, a variety of microorganisms seek to obtain nutrients for their survival by interacting with plants, where the interaction can be neutral, harmful (parasitism), or beneficial (mutualism or symbiosis) to the host (Shen et al., 2006; Thrall et al., 2007). However, most plants in natural ecosystems have been reported to display their high degree of colonization/symbiosis 
with mycorrhizal fungi and/or fungal endophytes (Rodriguez et al., 2009; Zuccaro et al., 2011). Biotrophy, necrotrophy and hemibiotrophy are among the major lifestyles that plantassociated fungi can exhibit (Zuccaro et al., 2011). The actively metabolizing plant tissues are required by biotrophic fungi where host is kept alive; whereas, the host is killed by necrotrophic fungi to obtain nutrients from the dead cells for their own growth and survival. The hemibiotrophic fungi belongs to an intermediate category, which requires living host cells during the initial part of their life cycles, and later acts as a necrotrophic fungi (Zuccaro et al., 2011).

Piriformospora indica, an axenically cultivable phytopromotional, biotrophic mutualistic root endosymbiont belongs to order Sebacinales (Basidiomycota) and has been reported to mimic capabilities of typical arbuscular mycorrhizal (AM) fungi. This fungus can colonize roots of a wide range of higher plants and provide plants multifaceted amenities (such as nutrient uptake, disease resistance, stress tolerance and growthpromotion involving value addition) (Unnikumar et al., 2013). In plant groups other than crops, for example orchids, $P$. indica has been reported to be primarily existed as a partner of mycorrhiza (Schäfer and Kogel, 2009). This fungus has been reported to perform multifarious functions, including its role in biological hardening during transplantation of micro-propagated plantlets (Singh et al., 2003), increased endogenous content of spilanthol after realization of its mutual interaction with medicinal plants such as Spilanthes calva (Rai et al., 2004). P. indica infestation in Helianthus annus and Aristolochia elegans has resulted into the stimulated synthesis of valuable compounds (Bagde et al., 2010a, 2014). Additionally, Bacopa monnieri co-cultivated with P. indica exhibited an enhanced growth, elevated bacoside endogenous level, antioxidant activity and nuclear hypertrophy (Prasad et al., 2013). Notably, compared to many other endophytes, P. indica can be cultured very easily in a bioreactor in order to prepare effective biofertilizer formulations (Singh et al., 2003; Oelmüller et al., 2009; Bagde et al., 2010b; Qiang et al., 2011). P. indica inocula are very effective for their commercial applications to various crops within the defined parameters viz., inocula quantity, inoculation time point, as well as soil selection for plant cultivation. Moreover, $P$. indica root endophyte has been credibly evidenced to minimize the use of chemical fertilizers, control crop yield, and also to provide increased resistance and tolerance in plants against biotic and abiotic stresses (Unnikumar et al., 2013). In our recent effort, $P$. indica-mediated improvements in the biomass, seed germination, plant growth and development and crop productivity under favorable environmental conditions were highlighted, and $P$. indica was argued as a powerful tool for crop improvement (Ansari et al., 2014).

Taking into account of recent literature, this paper: (a) overviews $P$. indica-strategies for root colonization; (b) gives insights into $P$. indica-plant mutualistic interaction and the role of calcium; (c) enlightens the association of $P$. indica with programmed cell death (PCD); (d) dissects information related with $P$. indica genome; (e) appraises literature available on $P$. indica-services to plants; (f) evaluates interaction of $P$. indica with other microorganisms, and appraises biotechnological significance of $P$. indica; (g) cross-talks information related with regulatory role of $P$. indica for the genes involved in plant metabolism, mineral uptake, in plant stress resistance and defense; and finally, (h) highlights the least explored aspects in the present context so far.

\section{Piriformospora indica-STRATEGIES FOR ROOT-COLONIZATION}

The fact that $P$. indica has a broad host range, which is not only confined to vascular plants but also to colonized mosses, implies that this fungus has evolved highly effective colonization strategies (Qiang et al., 2011). Some facts related with the lifestyle and the mechanisms underlying root colonization of $P$. indica from its interaction with many plants (such as Hordeum vulgare and Arabidopsis thaliana) have been unraveled (Deshmukh et al., 2006; Schäfer and Kogel, 2009). Generally, symbionts colonize rhizodermal and cortical cell layers of roots (Khatabi, 2009). Root colonization by $P$. indica is also known to start with interacellular chlamydospore germination and forming extracellular hyphal mats, and simultaneously penetrating rhizodermal and cortical cells (Deshmukh et al., 2006; Jacobs et al., 2011). As colonization proceeds, roots are densely covered with extracellular hyphae and harbor through inter- and intracellular networks; however, the fungus never enters into the vascular tissues. At cellular level, this fungus colonizes living root cells by its direct penetration (Jacobs et al., 2011). No microscopic evidence for impairment or even necrotization was found in $H$. vulgare and $P$. indica-colonized A. thaliana roots (Schäfer and Kogel, 2009). The colonization patterns of the various root regions harbor some quantitative as well as qualitative differences, which distinguish $P$. indica on $H$. vulgare (and A. thaliana) from endomycorrhizal fungi. The fungal root colonization increases with root maturation and the highest fungal biomass has been found in the differentiation, particularly in the root hair zones. Cytological studies have revealed the diverse types of $P$. indica-interaction with different root regions of $H$. vulgare, where the root hair zone (as the oldest root zone) was observed to be highly colonized by intracellular hyphae (Deshmukh et al., 2006). Cells in the differentiation zone can be filled with fungal hyphae reminiscent of hyphal coils (Deshmukh et al., 2006); whereas, scarcely and solely extracellularly colonization can be evidenced in the cells of meristematic zone (Schäfer and Kogel, 2009). Importantly, the physiological activity of host cells has been considered as a prerequisite for efficient nutrient exchange between the symbiotic partners (Schäfer and Kogel, 2009). Thus, root colonization pattern of $P$. indica differs from that of AM fungi, which are known to preferentially colonize younger root parts (Schäfer and Kogel, 2009) (Figure 1).

Zuccaro et al. (2011) presented the first in-depth genomic study and unveiled a mutualistic symbiont with a biphasic lifestyle. On the $25 \mathrm{Mb}$ genome of the mutualistic root symbiont $P$. indica, the authors characterized fungal transcriptional responses associated with the colonization of living and dead $H$. vulgare roots. A biphasic root colonization strategy of $P$. indica was revealed by microarray analysis, where a tightly controlled expression of the lifestyle-associated gene-sets was reported 


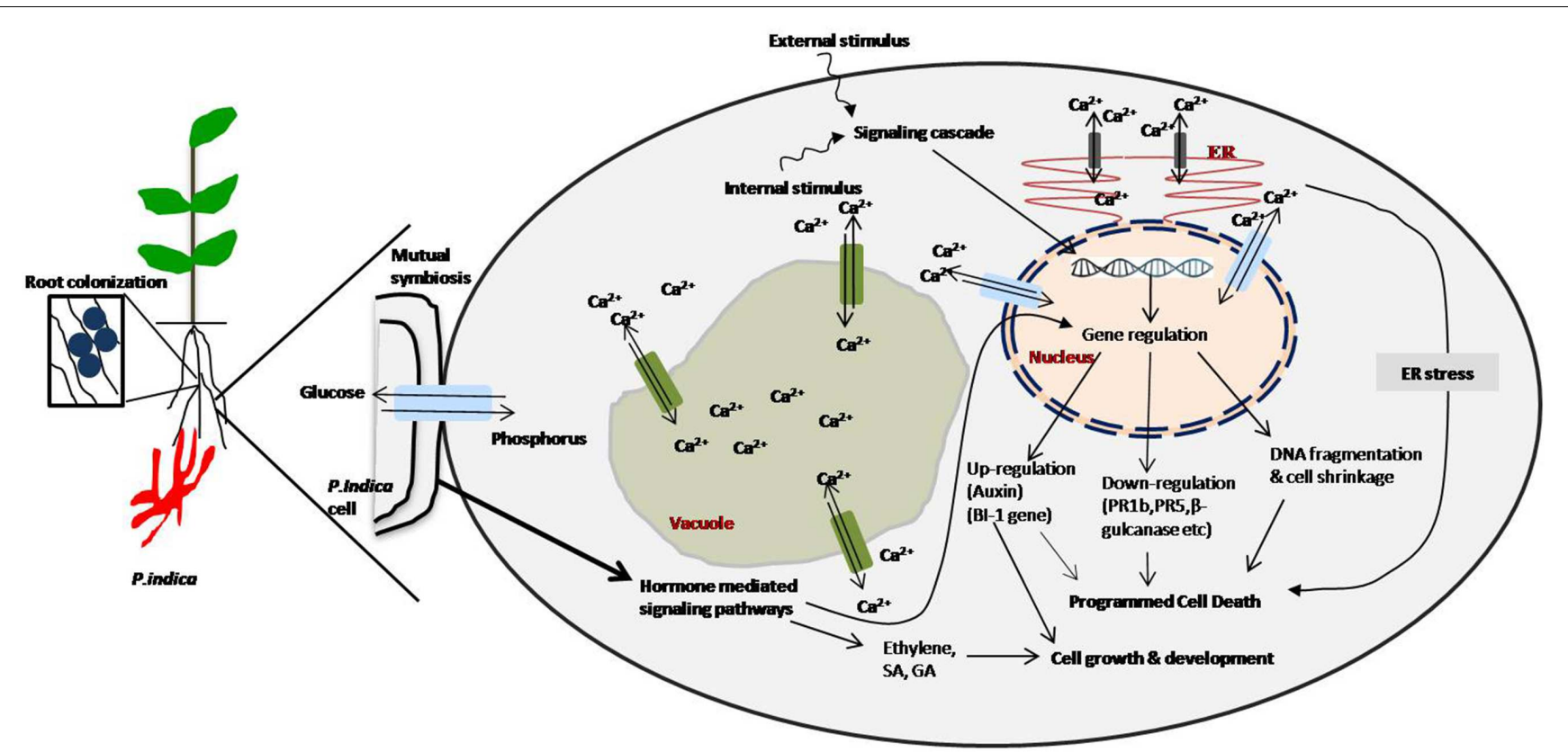

FIGURE 1 | Schematic representation of cellular and biochemical signaling cascades mediated by Piriformospora indica and plant colonization. Calcium signaling is induced by signals: $\mathrm{Ca}^{2+}$ efflux and influx homeostasis in vacuole, endoplasmic reticulum (ER) and nucleus by transporter, programmed cell death (PCD) induced by external and internal stimuli generated after P. indica colonization. PCD may be induced by genomic fragmentation and up and down regulation of few genes. PCD is also mediated by ER stress. Growth and development can be mediated by auxin, salicylic acid (SA) and ethylene phytohormones production and immune responses generated by gibberelic acid (GA) and jasmonic acid (JA) hormones-signaling (Hückelhoven, 2004; Lam, 2004; Deshmukh et al., 2006; Deshmukh and Kogel, 2007; Schäfer et al., 2009; Vadassery and Oelmüller, 2009; Jacobs et al., 2011; Qiang et al., 2011).

during the onset of the symbiosis. It has been observed that about $10 \%$ of the fungal genes induced during the biotrophic colonization encoded putative small secreted proteins (SSP). SSP included several lectin-like proteins and members of a $P$. indica-specific gene family (DELD) with a conserved novel seven-amino acids motif at the C-terminus (Zuccaro et al., 2011). The occurrence of the DELDs was further correlated with the presence of transposable elements in gene-poor repeatrich regions of the genome similar to the effectors found in other filamentous organisms. These findings together, helped to understand the development of biotrophic plant symbionts and also suggested a series of incremental shifts along the continuum from saprotrophy toward biotrophy in the evolution of mycorrhizal association from decomposer fungi (Zuccaro et al., 2011).

On the perspective of the biotrophic colonization pattern of $P$. indica, it has been reported that the $P$. indica biotrophic colonization pattern can be accompanied by a broad-spectrum suppression of root innate immunity (Qiang et al., 2011). In the support of the large host range of $P$. indica, molecular and genetic analyses revealed that plant roots, similar to leaves, are equipped with an effective innate immune system where immune suppression by $P$. indica was considered as a prerequisite for successful root colonization (Jacobs et al., 2011; Qiang et al., 2011). A little work has been performed in order to decipher the underlying mechanisms of suppression of root innate immunity by $P$. indica for a successful colonization. However, there are evidences that signify the involvement of several phytohormones in this context (Qiang et al., 2011). H. vulgare and Arabidopsis mutants impaired in gibberelic acid (GA) and jasmonic acid (JA) metabolism, respectively exhibited elevated root immune responses together with reduced root colonization (Schäfer et al., 2009; Jacobs et al., 2011). Studies have also revealed the dependency of $P$. indica on JA-mediated suppression of early immune responses (e.g., root oxidative burst) as well as salicylic acid (SA)- and glucosinolate-related defense pathways (Jacobs et al., 2011). For example, Arabidopsis mutants impaired in SAand glucosinolate-associated defense were reported to be more susceptible to $P$. indica (Sherameti et al., 2008; Jacobs et al., 2011). The disturbance of endoplasmic reticulum (ER) integrity by $P$. indica has been advocated to have potential for impairing the secretion of immunity-associated proteins (e.g., PR1 and PRRs) (Qiang et al., 2011). This suppression of early immune signaling (which disturbs immune execution) may potentially disarm the root, and thereby may facilitate root colonization. Since the genome of $P$. indica is available, it is possible to identify effector molecules targetting immune signaling components (Qiang et al., 2011).

\section{Piriformospora indica-PLANT MUTUALISTIC INTERACTION AND THE ROLE OF CALCIUM IONS}

Both mutualists and commensals are identical for many fungi during the initial phases of infection and colonization by 
pathogens (Rodriguez et al., 2004). Thus, the mode of recognition and early signaling processes are crucial in understanding how plants can differentiate between a beneficial and a detrimental microbe which in turn can modulate the expression of lifestyle in plants (Vadassery and Oelmüller, 2009; Singh et al., 2011). Notably, within seconds or minutes after the recognition of the two partners, an increase in the level of intracellular calcium $\left(\mathrm{Ca}^{2+}\right)$ in a plant cell has been considered as an early signaling event in the interaction of pathogenic, mycorrhizal or endophytic microbes with plants (McAinsh and Pittman, 2009). Nevertheless, in various plant-signaling pathways, $\mathrm{Ca}^{2+}$ ions act as a second messenger in order to couple extracellular stimuli with intracellular and whole plant responses (Sanders et al., 2002). Endophytic and mycorrhizal fungus interactions result in a better plant performance through sequential cytoplasmic and nuclear $\mathrm{Ca}^{2+}$ elevations (Vadassery and Oelmüller, 2009).

$\mathrm{Ca}^{2+}$ ions have been evidenced as a key participant in the mutualistic interaction of both $P$. indica and Arabidopsis. It is also one of the earliest signaling events during the recognition of these two symbionts, where a rapid induction of $\left[\mathrm{Ca}^{2+}\right]_{\mathrm{cyt}}$ elevation follows a nuclear $\mathrm{Ca}^{2+}$ response (Vadassery et al., 2009). Quite a few mutants which do not respond to $P$. indica concerning growth promotion and higher biomass production are also impaired in $\left[\mathrm{Ca}^{2+}\right]_{\text {cyt }}$ elevation. Additionally, elevations in the $\left[\mathrm{Ca}^{2+}\right]_{\text {cyt }}$ can also be induced by an autoclaved cell wall extract (CWE) from $P$. indica, which also can promote growth of Arabidopsis and other plant species (Vadassery et al., 2009). Previous facts together suggest insignificance of root colonization by the living fungus in the highlighted above response. Inductions in the elevation of $\left[\mathrm{Ca}^{2+}\right]_{\text {cyt }}$ by autoclaved CWE, preferentially in the roots confirm that the endophyte is a root-colonizing fungus. The very same CWE can induce a slightly different $\mathrm{Ca}^{2+}$ signature in tobacco roots hinting at the possibility of species-specific plant responses. CWE from $P$. indica also induces tuberization in vitro and promotes tuber growth and yield in potato due to increased transcript expression of the two $\mathrm{Ca}^{2+}$ dependant proteins (such as CaM1 and St-CDPK1) and the lipoxygenase (LOX) mRNA, which are known to play distinct roles in potato tuberization (Upadhyaya et al., 2013).

At the contact surface of plants, $P$. indica exchanges various signals which can result into influx of phosphorus and efflux of $\mathrm{Ca}^{2+}$ within plant cell (Yadav et al., 2010; Ansari et al., 2013). The external stimuli from endophyte signaling cascade of cellular network either signifies phytohormones to mainly be involved in PCD via endoplasmic reticulum stress or directly be involved in growth and development (Qiang et al., 2011; Ansari et al., 2013). Exhibition of the reduced colonization, plant growth and development were reported by the plant mutants impaired in GA and JA metabolism (Schäfer et al., 2009; Jacobs et al., 2011). Generally, in PCD, $\mathrm{Ca}^{2+}$ and phytohormone signal as internal or external stimuli that down-regulates (PR1b, PR5, $\beta$-gulcanase etc.) and up-regulates (auxin) (BI-1 gene) (Hückelhoven, 2004; Lam, 2004; Deshmukh and Kogel, 2007; Trivedi et al., 2013). PCD as DNA fragmentation and cell shrinkage were common during $P$. indica colonization (Deshmukh et al., 2006). The host cell death in $H$. vulgare plants via constitutively overexpressing the negative cell death regulator Bax Inhibitor-1 (BI-1) was reported to reduce colonization of roots (Deshmukh et al., 2006). Arabidopsis roots displayed ultrastructural alterations at the time of cell death that was linked with the colonization by $P$. indica. This can be explained by the fact that $P$. indica induces ER stress in colonized roots and also suppresses the adaptive ER stress response pathway (unfolded protein response, UPR) (Qiang et al., 2011, 2012). The inability of colonized cells to relieve ER stress via the UPR leads to activation of a pro-apoptotic signaling cascade (Qiang et al., 2011, 2012). Phytohormones and $\mathrm{Ca}^{2+}$ (which might occur at the plant-fungus interface) can direct the molecular and physiological processes responsible for the actual mechanism of $P$. indica colonization with plants providing various benefits to plants (Figure 2).

\section{Piriformospora indica AND PROGRAMMED CELL DEATH}

Generally, PCD is a natural response of plants to face physiological constraints provoked by varied internal or external stimuli (Hückelhoven, 2004; Lam, 2004). PCD is a metabolically regulated mechanism (e.g., nutrient recycling) vital for plant development. However, in the case of hypersensitive response (HR), PCD has a protective function in local and systemic tissue, characterized by defense gene expression to check the growth and propagation of pathogens (Heath, 2000; Hoeberichts and Woltering, 2003). Plant-PCD shares some common characteristics to apoptosis in animals such as chromatin condensation, cell shrinkage and DNA fragmentation followed by the nucleus breakdown (Heath, 1998). The fungal colonization of roots begins with a biotrophic growth phase, in which living cells are colonized, and followed by a cell deathdependent phase, in which root cells are actively killed by the fungus (Qiang et al., 2011). Earlier, P. indica was reported to colonize roots (such as that of Arabidopsis) by an initial biotrophic phase, which was evidenced to follow a cell deathdependent phase that may not show any disease symptoms on plant roots (Deshmukh et al., 2006). DNA fragmentation and cell shrinkage, common features of PCD can also be observed in $P$. indica-colonized roots (Deshmukh et al., 2006). It is assumed that $P$. indica uses these dead cells for intracellular sporulation (Qiang et al., 2011). In contrary to their pronounced induction during pathogen-induced HR (Heath, 2000), Deshmukh and Kogel (2007) argued that the kind of cell death occurred during $P$. indica colonization in $H$. vulgare may not be regarded as a microorganism-antagonizing plant response, since the defense marker genes (e.g., PR1b, PR5 and 1,3- $\beta$-glucanase) are weakly and transiently up-regulated solely at early interaction stages. Besides, accumulation of ROS (e.g., hydrogen peroxide, $\mathrm{H}_{2} \mathrm{O}_{2}$ ), as well as whole-cell auto-fluorescence mediated by phenolic compounds as characteristics of HR (Lamb and Dixon, 1997; Heath, 2000; Apel and Hirt, 2004) have never been detected in the P. indica colonized roots (Schäfer et al., 2007).

Transmission electron microscopic studies have revealed that cells are not dead at the penetration stages but show ultrastructural changes as cell-colonization is ascertained (Qiang et al., 2011). It implies that the fungal-colonization strategy is not 


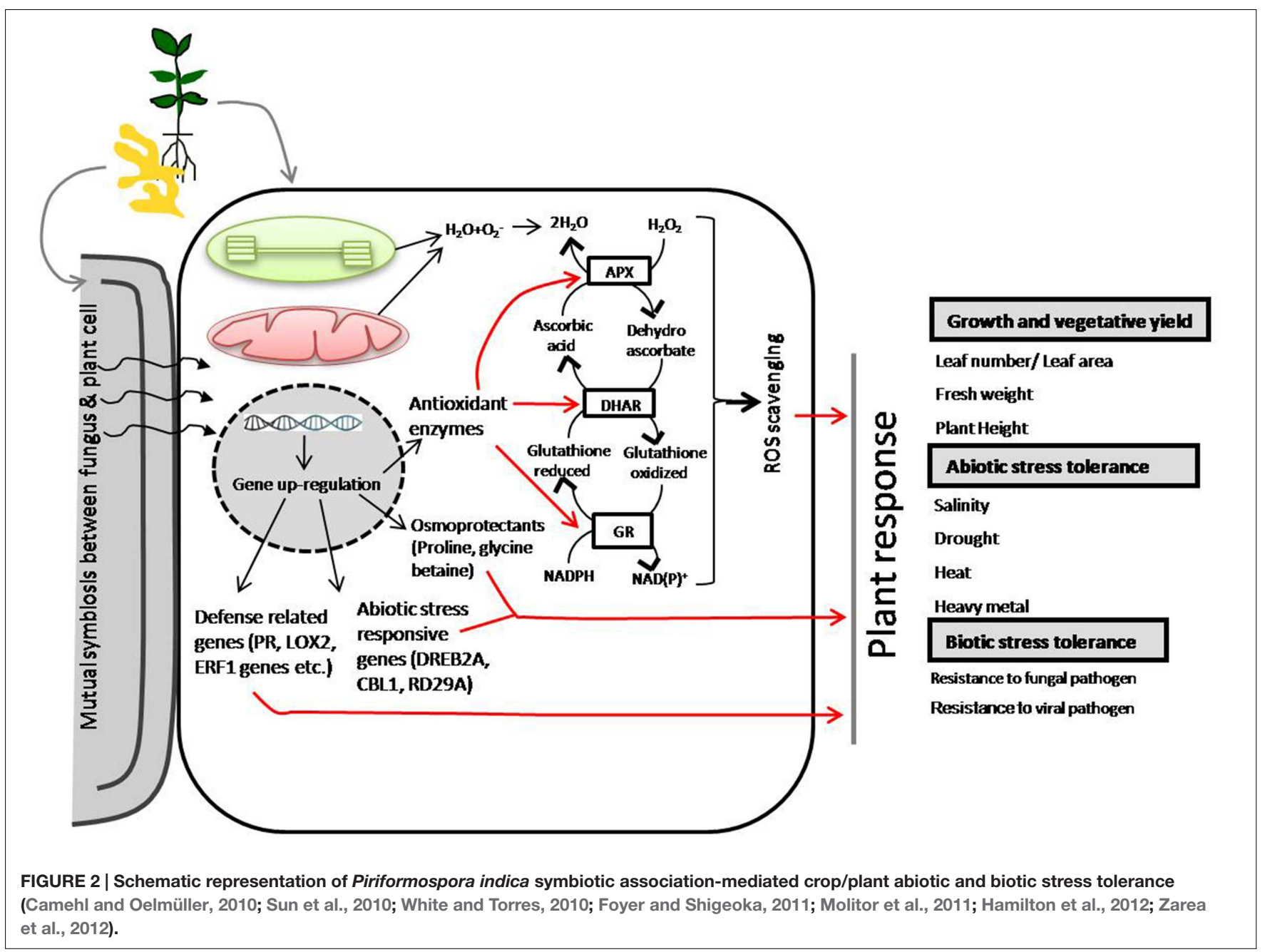

merely focused on the perception and subsequent colonization of dead cells though the penetrated host cells certainly die at one defined point of cell-colonization (Schäfer and Kogel, 2009). Evidences also confirm the dependency of this colonization strategy merely on the host cell death. Reduced colonization of roots was observed in $H$. vulgare plants constitutively overexpressing the negative cell death regulator Bax Inhibitor1 (BI-1) (Deshmukh et al., 2006). The expression of BI-1 in $P$. indica-infested $H$. vulgare was suppressed from 5 days after inoculation onward, which corresponded with cellular mycelial proliferation, and did not match with earlier root penetration events. Additionally, in comparison to the wild-type plants, the constitutive overexpression of $H v B I-1$ in $H$. vulgare led to a significant reduction in fungal biomass at 20 days after inoculation. These findings also agreed with the significant role of BI-1 in plant defense and cell survival (Schäfer et al., 2007). BI-1, known to be an integrator of ER stress, supports cell integrity and viability under unfavorable conditions. Besides its involvement in cell death, the ER is also significant for correct processing of immunity-related proteins with an extracellular (Wang et al., 2005) or plasma membrane-associated destination, including the pattern recognition receptor EFR (Nekrasov et al., 2009; Saijo et al., 2009). After recognition of the bacterial elongation factor TU, EFR activates basal immunity and effectively halts bacterial invasion of plants (Zipfel et al., 2006). Recent cellular analyses of Arabidopsis roots revealed ultrastructural alterations during cell death-associated colonization by $P$. indica (Qiang et al., 2011, 2012). According to these studies, $P$. indica induces ER stress in colonized roots, nevertheless, at the same time suppresses the adaptive ER stress i.e., unfolded protein response pathway (UPR). The inability of colonized cells to relieve ER stress via the UPR leads to activation of a pro-apoptotic signaling cascade. Thus, vacuolar collapse was identified to be downstream of ER stress and to represent a key element of the $P$. indica-induced cell death pathway. This vacuolar collapse has been considered essential for both cell death execution and root colonization, which is mediated by vacuolar processing enzymes (VPEs). For example, Arabidopsis mutants lacking VPEs were found incapable of undergoing cell death-associated vacuolar collapse and exhibited reduced fungal colonization (Qiang et al., 2011, 2012). It has been suggested that $P$. indica achieved its large host range through a biphasic colonization strategy, which consists of biotrophic accommodation by effective host immune suppression, followed by an ER stress-induced caspase-dependent vacuolar cell death. 
The exact execution of both colonization phases is a prerequisite for a successful symbiosis with Arabidopsis (Qiang et al., 2011, 2012). PYK10, a gene for an abundant $\beta$-glucosidease/myrosinase of $65 \mathrm{kDa}$ is located in the ER (Nitz et al., 2001; Matsushima et al., 2004) and has been identified as a target of $P$. indica in Arabidopsis roots (Peškan-Berghöfer et al., 2004; Sherameti et al., 2008). PYK10 was argued as a requirement for the beneficial interaction between Arabidopsis and P. indica (Sherameti et al., 2008). In fact, non-toxic glucosinolates can be hydrolyzed by myrosinases to biologically active isothiocyanates, thiocyanates, nitriles or epithio nitriles (Rask et al., 2000; Wittstock and Halkier, 2002). However, the nature of the aglycon moieties released from the substrates basically controls the biological function of a myrosinase. The involvement of these aglycons in the plant defense against herbivores and microbes has been reported (Stotz et al., 1999, 2000; Rask et al., 2000; Tierens et al., 2001). Thus, myrosinases can be exploited for their applications in plant biotic/abiotic stress defense.

Sherameti et al. (2008) hypothesized that the broad host range of $P$. indica is possibly due to its interaction(s) based on general recognition and signaling processes. In order to identify plant genes, which are targeted by the fungus, Arabidopsis mutants were screened that do not respond to the fungus with regard to growth promotion and enhanced seed production (Oelmüller et al., 2004; Shahollari et al., 2007). The authors reported that the growth of a T-DNA insertion line in PYK10 is not promoted and the plants do not produce more seeds in the presence of $P$. indica, although their roots are more colonized by the fungus in comparison with the wild-type roots. Overexpression of PYK10 mRNA did not affect either root colonization or the response to the fungus. The basic helix-loop-helix domain containing transcription factor NAI1 activates expression of PYK10, and two Arabidopsis lines with mutations in the NAI1 gene show similar response to $P$. indica as that of PYK10 insertion line. PYK10 transcript and PYK10 protein levels are severely reduced in a NAI1 mutant, signifying that PYK10 is responsible for the response to the fungus not the transcription factor NAI1. The message level for a leucine-rich repeat protein LRR1 is upregulated in wild-type roots in the presence of $P$. indica but not for plant defensin 1.2 (PDF1.2). Contrary to that, the message level for PDF1.2 is upregulated in the presence of the fungus in lines with reduced PYK10, not for LRR1. Sherameti et al. (2008) concluded that PYK10 restricts root colonization by $P$. indica, which leads into repression of defense responses and the upregulation of responses directing to a mutualistic interaction between the two symbiotic partners.

\section{Piriformospora indica GENOME - INSIGHTS TO SURPRISE}

A comparison of the $P$. indica genome with other fungi has revealed its classical features related with biotrophism as well as saprotrophism. The colonization of $P$. indica with Arabidopsis roots has been report to involve an initial biotrophic phase followed by cell death dependent phase, leading ultimately to no disease symptoms on roots (Deshmukh et al., 2006). However,
$P$. indica was reported to use the dead cells formed therein during the course of infection for intracellular sporulation (Qiang et al., 2011). The endophyte infection was earlier considered entirely symptomless, involving certain genes to indicate systemic root colonization by different fungal groups (Waller et al., 2008). Exhibition of biotroph-associated genomic adaptations has been evidenced in $P$. indica, where genes involved in $\mathrm{N}$ metabolism are lacking and also a limited potential is displayed by this mutualistic symbiont for host-damage and destruction (Zuccaro et al., 2011). In fact, $P$. indica lacks genes potentially involved in biosynthesis of toxic secondary metabolites and cyclic peptides. Nevertheless, genomic traits with saprotrophic and hemibiotrophic phytopathogenic fungi (such as the presence of an expanded enzyme arsenal which is weakly expressed during the initial biotrophic phase) are also shared by $P$. indica (Zuccaro et al., 2011). The analyses of the colonized young $H$. vulgare roots has revealed 579 genes in the phase of pre-penetration (36-48 hpi), 397 genes at early colonization (3 dpi) and 641 genes ( $5 \mathrm{dpi}$ ) as distinctively regulated when compared to fungal free roots (Zuccaro et al., 2011). In addition, the majority of genes $(\approx 40 \%)$ induced via symbiosis were found to be nonorthologous to either species; rather, these were reported specific to $P$. indica (Zuccaro et al., 2011). Plant hormones such as JA, methyl-jasmonate and ethylene signals from the roots were reported to decide the shoots to become preconditioned prior to foliar pathogens infection in $P$. indica-colonized roots via activating defense responses which in turn were evidenced to lead to enhanced disease resistance (Stein et al., 2008). In a signaling cascade, the JA (VSP, PDF1.2, LOX2) plus ET (ERF1) signaling and not the SA signaling $(P R 1, P R 5)$ genes were up-regulated in the $P$. indica plants in order to cope the powdery mildew fungus (Waller et al., 2005; Unnikumar et al., 2013). The indole3 -acetic acid (IAA) and ethylene role has been implicated in establishing a biotrophic symbiosis representing a compatibility factor at contact surface between endophyte and plants (Hilbert et al., 2012; Khatabi et al., 2012). The augmented intracellular $\mathrm{Ca}^{2+}$ pool after attaining the basic compatibility between the two partners in an early signaling event in the interaction of endophyte with plants (McAinsh and Pittman, 2009), acts as a second messenger in various plant signaling pathways (Sanders et al., 2002).

\section{Piriformospora indica-SERVICES TO PLANT COMMUNITY}

\section{Nutrient Acquisition}

Soil signifies a positive environment for a wide range of microorganisms including algae, bacteria, and fungi and the chemical changes that happen within the soil environment involve the active contribution of soil microflora (Prasad et al., 2015a). They chiefly participate in the processes which are necessary for plant growth and survival such as $\mathrm{C}$ and $\mathrm{N}$ cycle, nutrient acquisition and soil formation. On the other hand, owing to their role in $\mathrm{C}$-input in soils through root exudates, plants can also have profound effects on soil microbial communities especially those colonizing the rhizosphere (Khatabi, 2009). 
Being immobile organisms, plants have to cope with unfavorable conditions such as nutrient deficiency, salinity, drought, and pathogen attacks etc. Thus, to avoid such adverse situations, plants tend to establish their associations with beneficial microorganisms (Lum and Hirsch, 2003). In particular, symbiosis with beneficial fungi are known to be vital for nutrient acquisition by the root systems of most plants (Sirrenberg et al., 2007). Thus, application of beneficial microorganisms as biofertilizer plays a key role in today's agricultural scenario through enhancement of soil fertility and crop production. For example, mycorrhizal fungi and AM fungi under the order Glomales, are known to have symbiotic relationship with the majority of terrestrial plant species, where the fungi facilitate plants in their accession to soil nutrients, mainly phosphate (Harrison, 2005). Interestingly, AM symbiosis is described relatively primordial with that of rhizobium-legume association where 'Myc factor, a AM fungal signal, is a mixture of sulphated and non-sulphated simple lipochitooligosaccharides, might turn on signaling pathways having similar components of doesn't make infections (DMI)-signal transduction pathway to establish the mycorrhiza formation to promote plant growth (Maillet et al., 2011). Endophytic fungi $P$. indica which is phylogenetically close to mycorrhizal endosymbionts of orchid and ericoid roots has also been recognized as a growth promoter of numerous plant species (Varma et al., 1999; Weiss et al., 2004). Although mutual nutrient exchange through specialized structures is generally accepted as the main beneficial factor in mycorrhiza, however, major mechanisms of interaction in other endophytic systems are still not clear.

\section{$P$. indica and Acquisition of Phosphorous in Plants}

Phosphorous (P), one of the most essential mineral nutrients constitutes up to $0.5 \%$ of the dry weight of plant cell, and plays diverse regulatory, structural, and energy transfer roles (Balemi and Negisho, 2012). Plants cannot directly access P present in the soil as it is mostly in the form of scarcely soluble complexes; hence, its deficiency impedes crop production throughout the world (Balemi and Negisho, 2012). Plants acquire P from the soil through direct uptake by its own transporters and indirect uptake through mycorrhizal associations (Yadav et al., 2010). $P$. indica was reported to mediate the uptake of radiolabelled $P$ from the culture medium and its translocation to the host in an energy-dependent process (Varma et al., 2000). P. indica also produce significant amounts of acid phosphatases which can enable the host plant to access adequate amount of insoluble, condensed or complex forms of phosphate reserve in the soil (Singh et al., 2000). The association of $\mathrm{P}$ ectomycorrhiza and its role in plant P-aacquisition has been the focuss of recent studies (Becquer et al., 2014; Johri et al., 2015). Identification and characterization of high affinity phosphate transporters were also done in several plant and fungal species including A. thaliana, Medicago truncatula, Lycopersicon esculentum, Solanum tuberosum, Saccharomyces cerevisiae, and Neurospora crassa (reviewed by Johri et al., 2015). Notably, due to the lack of a stable transformation system in AM fungal species the role of phosphate transporters could not be established (MaldonadoMendoza et al., 2001). Isolation, identification, and functional characterization of a high affinity phosphate transporter from root endophyte fungus $P$. indica revealed the essentiality of phosphate transporter (PiPT) for phosphate transport to the host plant (Yadav et al., 2010). Nevertheless, the mechanism of this phosphate transfer from the fungus to the plant is not yet clear, though it has been hypothesized that the process might occur at the plant-fungus interface. This process essentially requires two transporters: the first to enable efflux of phosphate from the fungus and the second to mediate uptake of phosphate by the plant (Rausch and Bucher, 2002).

The reports concerning the involvement of $P$. indica in phosphate transfer and improvement in host plant are contradictory. Shahollari et al. (2005) reported that $P$. indica enhances the phosphate uptake 2-3 times higher in Arabidopsis seedlings and suggested that $P$. indica stimulates Arabidopsis growth in a manner parallel of mycorrhizal fungi. On the contrary, it has also been reported that $P$. indica does not induce significant increase of leaf $\mathrm{P}$ and $\mathrm{N}$ and phosphate has no role in the improved biomass of Nicotiana attenuata (Barazani et al., 2005). Yadav et al. (2010) reported that $P$. indica is involved in the phosphate transfer to the host Zea mays plant and proposed that involvement of PiPT in indirect phosphate transport to host plants presents the information regarding the molecular mechanism underlying $P$. indica-mediated phosphate transport to the host plant. However, it was resported earlier that $P$. indica does not induce potato phosphate transporter gene (StPT3) and that $P$. indica is not involved in the phosphate transfer to host plant (Karandashov et al., 2004). Correspondingly, no improved phosphate supply (a central mechanism of host plant fortification by AM fungi) was evidenced in $P$. indica $-H$. vulgare symbiosis (Achatz et al., 2010). However, the improved grain yield induced by the fungus was found to be independent of different $\mathrm{P}$ and $\mathrm{N}$ fertilization levels. Also, the total phosphate contents of host plant roots and shoots were not significantly affected by $P$. indica. The authors concluded that positive influence of $P$. indica on $H$. vulgare grain yield was independent of $\mathrm{P}$ and $\mathrm{N}$ supply and rather due to accelerated growth that leads to early development (Achatz et al., 2010).

Contrary to the reports discussed above, Yadav et al. (2010) found the impact of phosphate on the biomass of the Z. mays plant colonized with $P$. indica. Increased total phosphate content as well as biomass in the plants colonized with wild-type $P$. indica as compared with non-colonized and KD-PiPT $P$. indica-colonized plants were observed. These findings imply that phosphate play a significant role in the improvement of yield or biomass of Zea mays, and that enhanced biomass is in fact due to the PiPT. Furthermore, the growth-promoting activity (in terms of biomass) of $P$. indica was two-fold higher at low phosphate condition as compared with high phosphate condition (1.2-fold). Kumar et al. (2011) further investigated to ascertain whether growth-promoting activity of $P$. indica is an inherent trait of the fungus or it is dependent on the availability of $\mathrm{P}$, under P-rich and -deprived conditions. No significant change in the biomass was found at seedling stage; however, the difference in biomass was significant between colonized plants 
grown in $\mathrm{P}$ deprived conditions and non-colonized plants in rich $\mathrm{P}$ conditions at later stage. $P$. indica enhances biomass more efficiently in P-deprived condition than P-rich condition. The growth of colonized plant at $40 \mu \mathrm{M}$ phosphate was equal to non-colonized plants grown at $400 \mu \mathrm{M}$ indicating that $P$. indica can mimic the growth even at 10 -fold lower $\mathrm{P}$ supplement. Bicompartment assay for ${ }^{32} \mathrm{P}$ transportation revealed that the fungal hyphae transport $\mathrm{P}$ to host plant in $\mathrm{P}$-deprived condition but unable to transfer more $\mathrm{P}$ in P-rich condition though, there was no difference in the colonization at both the conditions. Hence, it has been concluded that $P$. indica has an ability to increase the biomass of the maize plant specifically under low phosphate condition thus; $P$. indica could be a good candidate for utilization in sustainable agriculture for the improvement of crop production in land deficient in P (Yadav et al., 2010; Kumar et al., 2011). Furthermore, RT-PCR analysis showed the expression of PiPT gene in P-deprived condition but not in P-rich condition. Therefore it was concluded that PiPT is actively involved in transporting $\mathrm{P}$ to the seedlings and that PiPT expression is dependent on the $\mathrm{P}$ availability. Though the mechanism for the transfer of $\mathrm{P}$ from $P$. indica to plant is not fully understood; however, it was hypothesized that $\mathrm{Pi}$ and organic $\mathrm{P}$ (such as polyphosphate) can be carried within the fungus by cytoplasmic streaming or by bulk flow to the plant root from external hyphae located in the soil (Kumar et al., 2011).

Conflicting results discussed above may be due to the hostspecific nature of $P$. indica since all the studies were conducted on different crop plants. Therefore, a complete range of different host plants would only provide a clear picture of whether $P$. indica and PiPT are host-specific or not. Exploitation of $P$. indica and its $P i P T$ not only can complement crop improvement strategies but may also serve as a model system to study molecular mechanism and indirect uptake of phosphate by plants (Yadav et al., 2010). Recently, the crystal structure of PiPT has been elucidated (Pedersen et al., 2013). With reference to the root colonization strategy of $P$. indica, i.e., the program cell death (Deshmukh et al., 2006), the authors emphasized that the main part of the root further develops and is not necrotized when colonized by the fungus. Hence, it was hypothesized that once the fungus releases phosphate into dead cells, it might be taken up by the non-affected living adjacent cells and further distribute into different parts of the plant (Deshmukh et al., 2006). Future research should be designed to perform gene function analysis studies in $P$. indica which has been a major constraint in genetic manipulation this fungus until now. In this context, the recently established electroporation-mediated transformation system based on the polyethylene glycol method for P. indica (Zuccaro et al., 2009) in combination with RNAimediated gene silencing (De Backer et al., 2002) have been suggested as major genetic engineering tools (Yadav et al., 2010).

\section{$P$ indica and Acquisition of other Major Nutrients in Plants}

Deficiency of other important nutrients such as nitrogen $(\mathrm{N})$ (Xu et al., 2012) and zinc (Zn) (Tsonev and Lidon, 2012) in soil has been reported to restrict plant growth and development. Plants recruit $\mathrm{N}$ either as nitrate or ammonium but in some species by $\mathrm{N}$ fixation with the help of rhizobia (Esseling and Emons, 2004). Mycorrhizal fungi also play an important role in delivering either nitrate or ammonium to the root cells. It is believed that mycorrhizal fungi preferentially recruit ammonium rather than nitrate from the soil and that amino acids represent the major compounds that serve to transfer nitrogen to the host plant (Guescini et al., 2003). Sherameti et al. (2005) reported that the co-cultivation of Nicotiana tabaccum and Arabidopsis seedlings with $P$. indica is accompanied by a huge transfer of $\mathrm{N}$ from the agar plates into the aerial part of the seedlings. This effect is associated with activation of the NADH-dependent nitrate reductase (NR), the enzyme which plays a key role in nitrate acquisition in plants. However, the stimulation of nitrate assimilation by $P$. indica is the reason for the growth promotion is not known. $P$. indica activates NR which in turn plays a key role in nitrate acquisition and also a starchdegrading enzyme, glucan-water dikinase is involved in the early events of starch degradation in N. tabaccum and Arabidopsis. $P$. indica also activates the expression of the genes for the starch-degrading enzyme, glucan-water dikinase (SEX1) in roots which is involved in early events of starch degradation in N. tabaccum and Arabidopsis. Both the growth promotion and stimulation of the two enzymes do not require heterotrimeric G-proteins. $P$. indica also stimulates the expression of the uidA gene under the control of the Arabidopsis NR (Nia2) promoter in transgenic tobacco seedlings. A homeodomain transcription factor responds to the fungus and binds to promoter regions of the $P$. indica-responsive Nia2, SEX1, and 2-nitropropane dioxygenase genes, indicating that the expression of $P$. indicaresponsive target genes may be controlled by common regulatory elements and trans-factors. It is proposed that the growth promoting effect initiated by $P$. indica is accompanied by a co-regulated stimulation of enzymes involved in nitrate and starch metabolisms. Application of bioinoculants prepared with the of fluorescent pseudomonas strains R81, and $P$. indica can efficiently promote growth in tomato plants probably due to the colonization strategies of plant growth promoting rhizobacteria (PGPR) and P. indica (Sarma et al., 2011). It has also been suggested that the better root density of the inoculated plants facilitate and improve uptake of the nutrients from the rhizosphere. Fluorescent pseudomonad strain (R81) being a phosphate solubilizing strain (Roesti et al., 2006) and acid phosphatases produced by $P$. indica were reported to mobilize and assist $L$. esculentum plant in phosphate-acquisition, and growth promotion (Sarma et al., 2011). Recently, a model has been proposed to study an interaction between different strains of Azotobacter and P. indica (Bhuyan et al., 2015). The interaction with $P$. indica is proposed as a useful tool for mitigating zinc (Zn)-deficiency stress in Triticum aestivum (Abadi and Sepehri, 2015). Improved uptake of mineral nutrients, antioxidant enzyme activities, photosynthetic pigments, and low lipid peroxidation have been observed in $T$. aestivum plants under $\mathrm{Zn}$-deficiency conditions with co-inoculation of two plant-growth-promoting microorganisms; Azotobacter chroococcum and P. indica (Abadi and Sepehri, 2015). 


\section{Seed Germination, Plant Growth and Development and Productivity}

Piriformospora indica can also significantly mediate improvements in the growth and yield of various crop plants, horticultural and medicinal plants (Varma et al., 2001; PeškanBerghöfer et al., 2004; Pham et al., 2004; Vadassery et al., 2008; Kumar et al., 2009; Oelmüller et al., 2009; Achatz et al., 2010; Fakhro et al., 2010; Gosal et al., 2010; Sun et al., 2010). P. indicainduced seed germination and development have been reported in several crop plants (Varma et al., 2012a,b, 2013). P. indicamediated seed development and enhanced seed production in A. thaliana were reported as a result of the pii-2 and At5g16590 located in the micro-domains of plasma membrane (Shahollari et al., 2007). $P$. indica-inoculated $H$. vulgare seeds exhibited higher viability (Harrach et al., 2013). Moreover, germinated seedlings immersed in $P$. indica-homogenate exhibited a good survival rate under adverse conditions (Harrach et al., 2013). $P$. indica filtrate can facilitate early seed germination in vascular plants (Adya et al., 2013). In Helianthus annus, P. indica culture filtrate was evidenced to influence the seed-oil yield (Bagde et al., 2011). A higher seed yield was also reported in the members of bryophytes, pteridophytes, gymnosperms and angiosperms as a result of the colonization of $P$. indica in their roots (Varma et al., 2012a,b) (Table 1).

The role of $P$. indica inoculation/colonization in medicinal plants has been considered of utmost significance (Das et al., 2012). The colonization of $P$. indica has been reported in a number of medicinal plants including Coleus forskohlii, Bacopa monnieri, Stevia rebaudiana, Artemisia annua, Linum album, Trigonella foenumgraecum, Spilanthes calva, Withania somniferra, Chlorophytum borivilianum, Curcuma longa, Podophyllum peltatum, Azadirachta indica, Oscimum sanctum, Linum album and Lantana camara (Oelmüller et al., 2009; Das et al., 2012; Sharma and Agarwal, 2013; Kumar et al., 2013, 2015; Ahlawat et al., 2015) (Table 2). Increased contents of chemical compounds and secondary metabolites were reported in P. indica-colonized C. forskohlii (Das et al., 2012). P. indica has also been reported to enhance the growth, bacoside endogenous level, antioxidant activity as well as hypertrophy of nuclei in B. monnieri (Prasad et al., 2013). Medicinal properties of A. indica, A. elegans, and $H$. annuus were increased with their colonization with P. indica (Bagde et al., 2010b). P. indicainoculation in L. album cell culture improved the production of anticancer drug podophyllotoxin (Kumar et al., 2013). Leaf area and fresh biomass were improved in herbaceous plants namely $S$. rebaudiana and $A$. annua with their cultivation with P. indica (Varma et al., 2013). Earlier, Rai et al. (2001) reported a positive response of the growth of medicinal plants such as $S$. calva and $W$. somnifera in a field trial with $P$. indica inoculum (Table 2). Recently, in vitro co-cultivation of $P$. indica filtrate was reported to improve biomass productivity in A. annua and W. somniferra (Ahlawat et al., 2015; Baishya et al., 2015). Cell suspension cultures of $W$. somnifera offers the potential for continuous production of withaferin A (Ahlawat et al., 2015). Further, it can be concluded that the symbiotic effect of $P$. indica can be used as a biopriming agent for the overall growth of plant biomass.
On the perspective of $P$. indica colonization role in crop plants, $P$. indica-mediated improvements in the growth and biomass have been reported in a number of crop plants including Oryza sativa, Saccharum officinarum, Abrus precatorius, Zea mays, Phaseolus vulgaris, and Tridax procumbans (Prasad, 2008; Varma et al., 2012a,b, 2013, 2014). P. indica can produce auxin (IAA) which in turn can promote plant root growth (Sirrenberg et al., 2007). In contrast to the auxin mediated least impact on the regulation of the gene expression in Arabidopsis (Vadassery et al., 2008), auxin regulated gene expression was found upregulated in H. vulgare (Schäfer et al., 2009) and Chinese cabbage (Lee et al., 2011). Interestingly, $P$. indica has been reported to interfere with ethylene signaling in plants where, it promotes the plant growth (Barazani et al., 2007). However, the exact mechanism underlying $P$. indica-mediated ethylene signaling inhibition is still unclear in plants (Hayat et al., 2010). The stimulation of secondary metabolite synthesis by the endophytic fungus, $P$. indica has also been reported for the production of pentacyclic triterpenoids (e.g., ursolic acid, oleanolic acid and betulinic acid) in the suspension cultures of L. camara (Kumar et al., 2015).

\section{Abiotic and Biotic Stress Tolerance}

Piriformospora indica has been extensively reported to improve crop tolerance to a number of abiotic stresses including salinity, low temperature and heavy metal toxicity (Baltruschat et al., 2008; Sun et al., 2010; Husaini et al., 2012; Zarea et al., 2012; Ansari et al., 2013; Unnikumar et al., 2013). P. indica colonization-mediated high salinity tolerance was reported in Triticum aestivum (Zarea et al., 2012), that of drought stress tolerance in Arabidopsis seedlings (Sherameti et al., 2008), Chinese cabbage (Sun et al., 2010) and strawberry (Husaini et al., 2012). P. indica colonization has extensively been reported to mediate the activation of defense related genes (such as $P R, L O X 2$, and ERF1 genes) (Zarea et al., 2012), abiotic stress responsive genes (DREB2A, CBL1, RD29A) (Ansari et al., 2013) and osmoprotectants (proline, glycine betaine) (Waller et al., 2005; Trivedi et al., 2013) (Figure 3). The interaction of $P$. indica with A. thaliana roots is a unique model system to study symbiotic relationships. Recently, Vahabi et al. (2015) has reported a cocultivation system which allowed them to investigate the effects of fungal exudates on the root transcriptome before and after the establishment of a physical contact, and during early phases of root colonization.

Mutualistic fungi $P$. indica has also evolved the ability to deliver molecules, called effectors, inside the cells to enhance microbial infection, and manipulate the host metabolism (Kloppholz et al., 2011; Plett et al., 2014). The effector protein is involved in the establishment and maintenance of symbiosis in endo- and ectomycorrhiza, allowing the fungus to manipulate the plant defense response (Kloppholz et al., 2011; Plett et al., 2011, 2014). Recently, Akum et al. (2015) reported the function of $P$. indica effector candidate PIIN_08944, a non-DELD effector, during the interaction of plants with $P$. indica. The authors noted the contribution of the candidate effector to plant colonization where the mutualistic fungus suppressed the salicylate -mediated basal resistance response (Akum et al., 2015). Effector protein, PIIN_08944 expression was detected during chlamydospore 
TABLE 1 | Summary of representative recent studies highlighting beneficial roles of Piriformospora indica in major crops/plants under normal, and biotic and abiotic stress conditions.

Plants/host plants
Normal/non-stress conditions
Hordeum vulgare
Brassica campestris sp. Chinensis
Tridax procumbens
Cyclamen persicum

Foeniculum vulgare

Helianthus annus

Centella asiatica

Jatropha and Populus

Oryza sativa

Nicotiana attenuata

Lycopersicon esculentum (Tomato)

Vegetable crops

\section{Biotic stresses}

A. thaliana

A. thaliana
A. thaliana
A. thaliana
H. vulgare
L. esculentum

L. esculentum

Triticum aestivum

Abiotic stresses
Hordeum vulgare
H. vulgare
H. vulgare

H. vulgare

Nicotiana tabacum

Oryza sativa

Sesamum indicum

T. aestivum

Solanum lycopersicum

T. aestivum

Beneficial roles

Reference

Increase in seed viability and survival, and vegetative and grain yields

Increase in root and shoot fresh weight

Increase in root and shoot length and fresh and dry weight Increase in the numbers of flowers and unfolded leaves; Increase in the proportion of homogeneous microspores and viable pollen and ovules

Increase in plant height, shoot and root dry weight, number of inflorescence

Higher seed yield with increased oil content, Lipid biosynthesis

Increase in plant fresh weight, leaf and root number

Early seed germination, and increase in seed formation and seed yield

Improved root and shoot length and dry weight

Increase in stalk length, number of flower/plant, seed

weight and root fresh weight

Increase in seedling growth

Induced seed germination, Seed formation, seed value and yield

Significant reduction in Verticillium dahlia-mediated disease development

Protection against verticillium wilt and root rot caused by Verticillium longisporum and Rhizoctonia solani, respectively.

Protection against leaf blight caused by Alternaria brassicae Protection against Verticillium wilt caused by $V$. dahlia Protection against rhizoctonia root rot caused by Rhizoctonia solani

Protection against Fusarium wilt and black root rot caused by Fusarium oxysporum and Thielaviopsis basicola, respectively.

Protection against yellow leaf mosaic and Verticillium wilt caused by Pepino mosaic virus and $V$. dahlia, respectively Protection against Fusarium head blight disease isolates and mycotoxin (deoxynivalenol) contamination

Increase salinity tolerance as indicated by increasing the foliar potassium $\left(\mathrm{K}^{+}\right)$/sodium $\left(\mathrm{Na}^{+}\right)$ratio

Drought stress tolerance

Increases in the biomass of aerial parts; increased the $\mathrm{K}^{+} / \mathrm{Na}^{+}$and $\mathrm{Ca}_{2}{ }^{+} / \mathrm{Na}^{+}$ratios, and increase in salinity tolerance

Increase in crop yield under low temperature stress

Enhanced cadmium tolerance

Increase in salinity stress

Increase in growth and tolerance to drought stress

Increase in cadmium stress tolerance

Osmotic stress and chloride toxicity

Mitigation of zinc deficiency stress
Harrach et al., 2013

Sun et al., 2010; Lee et al., 2011

Das et al., 2013

Ghanem et al., 2014

Dolatabadi et al., 2012

Bagde et al., 2011

Satheesan et al., 2012

Varma et al., 2013

Jogawat et al., 2013

Schuck et al., 2012

Anith et al., 2015

Varma et al., 2012a,b, 2013

Sun et al., 2014

Knecht et al., 2010

Johnson et al., 2013

Sun et al., 2014

Qiang et al., 2012

Qiang et al., 2012

Fakhro et al., 2010

Rabiey et al., 2015

Alikhani et al., 2013

Ghabooli et al., 2013

Ghabooli, 2014

Murphy et al., 2014

Hui et al., 2015

Jogawat et al., 2013

Zhang et al., 2014

Shahabivand et al., 2012

Al-Absi and Al-Ameiri, 2015

Abadi and Sepehri, 2015 
TABLE 2 | Summary of representative recent studies highlighting beneficial roles of Piriformospora indica in major medicinal plants.

\begin{tabular}{|c|c|c|}
\hline Plants/Host plants & Beneficial roles & Reference \\
\hline Aloe vera & Improved micropropagation, growth and phytochemical content & Sharma et al., 2014 \\
\hline Artemisia annua & Increased biomass productivity & Baishya et al., 2015 \\
\hline $\begin{array}{l}\text { Azadirachta indica, } \\
\text { Aristolochia elegans, and } \\
\text { Helianthus annuus }\end{array}$ & Enhanced biomass production and increased medicinal property and yield & Bagde et al., 2010a \\
\hline Bacopa monnieri & Increase in growth, and bacoside endogenous level and antioxidant activity & Prasad et al., 2013 \\
\hline Coleus forskohlii & $\begin{array}{l}\text { Increase in growth parameters, aerial biomass and in important metabolites } \\
\text { production for medicinal application }\end{array}$ & Das et al., 2012, 2014 \\
\hline Curcuma longa & Increase in yield and active ingredients. & Bajaj et al., 2014 \\
\hline Herbal medicinal plants & $\begin{array}{l}\text { Increased vegetative growth, and Increased quality and quantity of herbal } \\
\text { medicine }\end{array}$ & Das et al., 2012 \\
\hline Linum album & Biosynthesis of podophyllotoxin production & Kumar et al., 2013 \\
\hline $\begin{array}{l}\text { Stevia rebaudiana and } \\
\text { Artemisia annua } \\
\text { Chlorophytum borivilianum }\end{array}$ & $\begin{array}{l}\text { Prominent leaf area and improved vegetative growth/yield early flowering in the } \\
\text { crop and } 90 \% \text { survival on transplantation enhancement of the antifungal activity } \\
\text { and quantity of spilanthol net primary productivity enhanced }\end{array}$ & $\begin{array}{l}\text { Varma et al., } 2013 \\
\text { Prasad et al., } 2008\end{array}$ \\
\hline $\begin{array}{l}\text { Spilanthes calva } \\
\text { Withania somnifera }\end{array}$ & & $\begin{array}{l}\text { Rai et al., 2004; Prasad et al., } 2008 \\
\text { Prasad et al., } 2008\end{array}$ \\
\hline Lantana camara & $\begin{array}{l}\text { The production of pentacyclic triterpenoids e.g., ursolic acid, oleanolic acid and } \\
\text { betulinic acid }\end{array}$ & Kumar et al., 2015 \\
\hline W. somnifera & Stimulate plant growth and metabolism & Ahlawat et al., 2015 \\
\hline
\end{tabular}

germination, and fungal deletion mutants $\left(\mathrm{Pi}_{\Delta} 08944\right)$ showed delayed root colonization. PIIN_08944-expressing A. thaliana showed a reduced expression of flg22-induced marker genes of pattern-triggered immunity (PTI) and the SA-defense pathway. In H. vulgare, the expression of PIIN_08944 reduced the burst of reactive oxygen species (ROS) triggered by flg22. Therefore, PIIN_08944 was advocated to contribute to the root colonization by $P$. indica by interfering with SA-mediated basal immune responses of the host plant (Akum et al., 2015).

Piriformospora indica has also been reported to modulate major antioxidant defense enzymes monodehydroascorbate reductase and dehydroascorbate reductase (Vadassery et al., 2009; White and Torres, 2010; Foyer and Shigeoka, 2011; Hamilton et al., 2012) and the other components of ROS-scavenging system (Waller et al., 2005; Sun et al., 2010). P. indica-colonization was reported to mediate the up-regulation in a number of enzymes involved in ROS-metabolism in salinity exposed plants (Baltruschat et al., 2008). In addition, the establishment of ROS-scavenging system as a result of $P$. indica inoculation has been reported to confer plant tolerance to major abiotic stresses including salinity, drought, heat and heavy metal, and protection against fungal and viral pathogens (Waller et al., 2005; Serfling et al., 2007; Kumar et al., 2009; Sun et al., 2010; Ansari et al., 2013). Interestingly, down-regulation of genes encoding enzymes for ascorbate synthesis in Arabidopsis exhibited a greater colonization by this endophyte (Vadassery et al., 2009). However, a greenhouse study of 'Hildares' tomato (Solanum lycopersicum Mill.) inoculation with $P$. indica under osmotic stress and specific chloride toxicity conditions showed insignificant increases in the growth of $P$. indica-inoculated plants grown under severe salinity stress, and the responses corresponded a significant increase in $\mathrm{CO}_{2}$ assimilation rate in the final harvest and leaf water potential and transpiration rate in the first harvest (Al-Absi and Al-Ameiri, 2015). Though the mechanisms underlying $P$. indica-induced resistance has already been much explained for abiotic and biotic stress response in rhizobacteria-colonized plants little is known for mechanisms underpinning $P$. indica-induced resistance in abiotic and biotic stressed-plants (Van Wees et al., 2008).

Piriformospora indica has its well defined roles in the protection of plants against a range of biotic stress factors such as pathogenic fungi, bacteria and virus (Waller et al., 2005; Serfling et al., 2007; Oelmüller et al., 2009; Camehl et al., 2010, 2013; Molitor et al., 2011; Dolatabadi et al., 2012; Johnson et al., 2013). The analyses of the beneficial interaction between $P$. indica and host plants has revealed the upregulation of various defense related genes including pathogenesis related $P R$ genes, jasmonate JA (VSP, PDF1.2, LOX2) and ethylene ET (ERF1) signaling genes in response to pathogen attack (Camehl et al., 2010; Molitor et al., 2011) (Figure 3). P. indica has found to confer protection to $H$. vulgare plant against root damage caused by Fusarium culmorum and against shoot infection with Blumeria graminis (Waller et al., 2005). Many root pathogens have been found to be directly inhibited by antagonistic activities of the endophytic fungus except F. culmorum (Waller et al., 2005), P. herpotrichoides (Serfling et al., 2007), F. oxysporum (Dolatabadi et al., 2012). To the other, systemically induced resistance by $P$. indica root-colonization has also been reported for many leaf pathogens. Recently, in root endophyte-colonized $H$. vulgare plants, a sub-set of defense-related genes was observed highly induced by leaf pathogens (Molitor et al., 2011). The role of $P$. indica in the protection of a number of plants against losses due to fungal pathogens infection has been summarized in Table 1.

Piriformospora indica has been credibly reported to defend crop plants against attack of viral as well as fungal pathogens and thereby providing them a better vegetative or generative development (Camehl et al., 2013). Recently, P. indica has been found to provide massive bioprotective potential to economically 


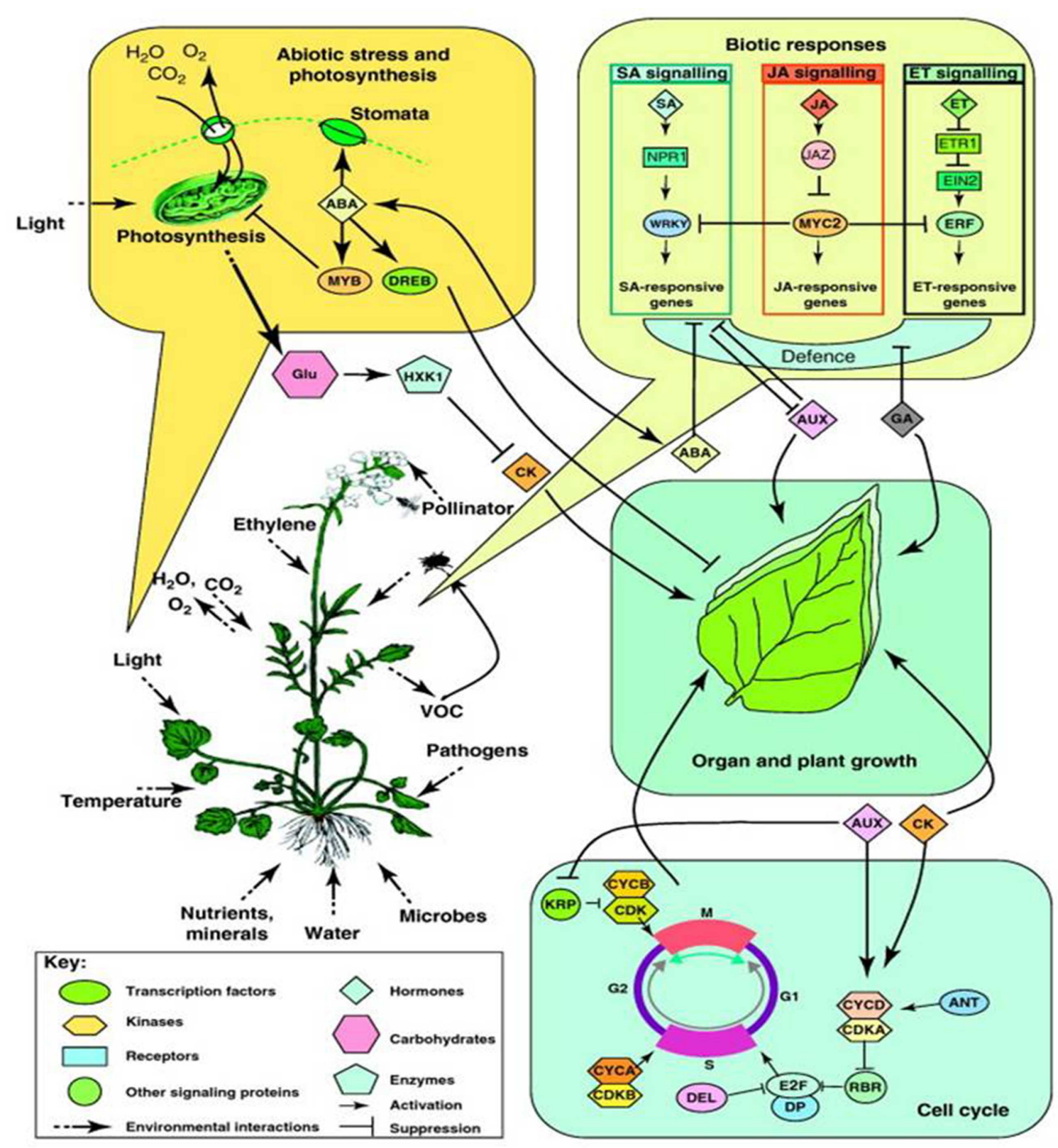

FIGURE 3 | Overview of biotic and abiotic stress responses in plants in nature. A perceived stress factor induces changes at the cellular level (e.g., the cell cycle) that translate to the individual level (e.g., organ and plant growth; abiotic stress and photosynthesis) and influences interactions with other species (e.g., biotic responses). (Reprinted with permission from Keurentjes et al. (2011). Copyright Trends in Plant Science, Elsevier).

important different agricultural and horticultural crops against various plant pathogens and insect pests attack (Varma et al., 2012a). P. indica fungus could be utilized to increase fungal disease resistance in plants where, $P$. indica-infested crop plants were reported to exhibit their additional resistant against pathogenic fungi (Waller et al., 2005). H. vulgare plants subjected to the fungal pathogen such as F. culmorum, become free from root diseases when colonized with $P$. indica. Similarly, $P$. indica treated plants were also protected against root-pathogenic Cochliobolus sativus fungus (Oelmüller et al., 2009). P. indica fungus-mediated improved resistance of $H$. vulgare has been noted against the attack of root- and leaf-pathogens such as Fusarium culmorum and Blumeria graminis (Waller et al., 2005). Recently, $P$. indica colonized $H$. vulgare roots incited systemic resistance against the biotrophic leaf pathogen $B$. graminis f. sp. hordei (Molitor et al., 2011). P. indica was reported to be an effective candidate in biocontrol of take-all diseases of T. aestivum (such as Gaeumannomyces graminis var. tritici) (Ghahfarokhi and Goltapeh, 2010) and Fusarium wilt disease of lentil (Dolatabadi et al., 2012). Greenhouse experiments on $P$. indica-colonization 
with winter $T$. aestivum's roots were resulted into significant reduced of incidence of leaf, stem, and root diseass caused by $B$. graminis f. sp. tritici, Pseudocercosporella herpotrichoides and $F$. culmorum. In a field trial, $P$. herpotrichoides infection was considerably decreased in endophyte-colonized plants. Systemic resistance against B. graminis attack was induced in $P$. indica-colonized plants (Serfling et al., 2007). P. indicainduced powdery mildew (Golovinomyces orontii) resistance in Arabidopsis necessitated JA-signaling involving JA-regulated genes to confer $G$. orontii tolerance. Furthermore, fungus has been evidenced to require merely cytosolic and not nuclear localized NPR1 to provoke systemic induced resistance in Arabidopsis (Stein et al., 2008). Recent reports have evidenced that $P$. indica-induced GA can positively modulate plant defense response in roots. It has similar potential to induce systemic resistance (ISR) like Trichoderma spp. Pathogens attack requires basic compatibility to attain with their host plants involving definite upstream regulatory genes. The key mechanism has been defined either in rhizobacteria-mediated ISR or by plant inoculation with $P$. indica. Nevertheless, the majority of expression studies regarding $P$. indica-host communication center on root physiology. Further, systemic stimulation of a small number of defense-related genes or proteins have been depicted based on more or less a similar mechanism (Shoresh et al., 2010; Camehl et al., 2013).

\section{Piriformospora indica-INTERACTION WITH OTHER MICROORGANISMS}

Piriformospora indica interaction (antagonism and cooperation) with other microorganisms has been reported to improve plant protection against environmental stresses (Pham et al., 2004; Porras-Alfaro and Bayman, 2011). P. indica interacts with a diverse group of microorganisms such as Sebacina vermifera, Pseudomonas fluorescens (rhizobacteria), Chlamydomonas reinhardtii, G. graminis, and other soil fungi (i.e., Aspergillus niger, A. sydowii and Rhizopus stolonifer). P. indica invaded $H$. vulgare roots were reported resistant against Fusarium infections (Deshmukh et al., 2007). These authors provided evidences that pathogenesis-related (PR) proteins do not affect $P$. indica-mediated response to confer resistance against Fusarium infections. $P$. indica was found to diminish the severity of disease caused by $V$. dahliae (Fakhro et al., 2010). The interaction of $P$. indica with the Pepino mosaic virus (PepMV) was evaluated in hydroponically grown L. esculentum where, the authors observed $30 \%$ reduction on the disease severity by $V$. dahliae (Fakhro et al., 2010). The growth of pathogenic fungi such as $A$. sydowii, $R$. stolonifer and $A$. niger has been reported to be entirely obstructed by $P$. indica. However, stimulation was noticed in the growth of the alga such as $C$. reinhardtii when cultured with $P$. indica. Though $P$. indica interacts with diverse class of bryophyte including mosses and liverworts but no growth promotion has been reported as a result of the interaction (Pham et al., 2004).

Among the Sebacinales, $P$. indica shows its interaction with $S$. vermifera in addition to multinucleate Rhizoctonia
(Schäfer and Kogel, 2009). The pure cultures of closely related species such as $P$. indica and $S$. vermifera were reported essential for the germination, growth, development and yield and herbivore resistance of Nicotiana attenuate (Barazani et al., 2005). It has been reported that $P$. indica, S. vermifera and Trichoderma species act as effective biocontrol agent for take-all diseases in T. aestivum (Ghahfarokhi and Goltapeh, 2010). P. indica has been reported to support the growth and development of Azotobacter chroococcum, Azospirillum brasilensis, and Bradyrhizobium sp.; however, P. indica-mediated inhibition was noted in Pseudomonas fluorescens (Malla and Pokhare, 2008). Interestingly, there is an evidence that P. indica subsist rod-shaped 1-1.5 $\mu \mathrm{m}$ long bacteria in its cytoplasm and is characterized as Rhizobium radiobacter (Sharma et al., 2008). In a field experiment, $P$. indica-colonized plants exhibited significantly reduced disease severity caused by $P$. herpotrichoides (Serfling et al., 2007). P. indica and R. leguminosarum inoculated Phaseolus bean along with vermicompost revealed enhanced length and dry weight of both root as well as shoot with respect to treatment either deficient in vermicompost or with single inoculation (Tuladhar et al., 2013). P. indica either alone or in an interaction with $S$. vermifera, Trichoderma viride and T. harzianum was found to be more effective in reducing the severity of Fusarium wilt disease of lenti (Dolatabadi et al., 2012).

The studies on $18 \mathrm{~S}$ rRNA and 20S rRNA sequence identity have revealed the fact that $P$. indica is closed relatives to the Rhizoctonia group and Sebacinaceae (Basidiomycetes) (Singh et al., 2003). In adition, P. indica affinity with Glomeromycota members such as Glomerales, Diversisporales as well as Archeosporales has been deciphered through P. indica characterization via immunofluorescence, Western blot, enzymelinked immunosorbent assay along with immuno-gold (Singh et al., 2003). In response to signals from $P$. indica, MATH protein, LRR1, LRR2, PDK, OXII, MAPK genes were upregulated in the roots of $A$. thalina prior to colonization (Vadassery et al., 2009). On the other hand, $\left[\mathrm{Ca}^{2+}\right]_{\text {cyt }}$ either induced various signaling course of actions, or defense interrelated responses were suppressed by supplementary factors (e.g., effectors) liberated by the fungus. These signaling events may be useful to understand the interactions of other beneficial fungi associated with economically important diverse crops for possible biotechnological applications (Oelmüller et al., 2009; Varma et al., 2013).

\section{Piriformospora indica - BIOTECHNOLOGICAL SIGNIFICANCE-APPRAISAL}

\section{$P$ indica as a Bio-control Agent and Plant Stress Response Mediator}

It is believed that $P$. indica-colonization results into the activation of antioxidant system, which in turn improves crop plant tolerance against abiotic as well as biotic stresses (Prasad et al., 2013). The bio-protection performance of $P$. indica in T. aestivum has been evidenced against B. graminis f. sp. tritici, 
P. herpotrichoides and Fusarium culmorum (Serfling et al., 2007), and in $Z$. mays against the root parasite Fusarium verticillioides (Kumar et al., 2009). The fungus colonized plants were less susceptible to Alternaria alternate and Colletotrichum falcatu compared to non-colonized plants (Varma et al., 2012a). The ability of $P$. indica to synthesize hydroxamic acids - a secondary metabolite has been reported, which functions like a natural pesticide (Varma et al., 2001). The significance of $P$. indica as a bio-fertilizer as well as a bio-control agent has been strongly advocated (Waller et al., 2005; Varma et al., 2012a,b). Now, $P$. indica has become a paramount important candidate in microbiological and biotechnological research revealing several positive consequences on diverse crop plants (Barazani and Baldwin, 2013).

Ethylene, a gaseous plant hormone is produced in the majority of plant cells and controls various aspects of plant growth and development. Its positive and/or negative consequences has already been realized on flower, fruit ripening and leaf epinasty and abscission, suppression of apical dominance, leaf senescence, PCD, root nodulation, seed dormancy, seed germination and responsiveness to environmental stress including pathogen attack (Sharafzadeh, 2012; Varma et al., 2012a,b). The beneficial interaction of $A$. thaliana roots with mutualistic root endophytic fungus $P$. indica has been reported to induce ethylene, a gaseous plant hormone (Khatabi et al., 2012). Ethylene contributed a significant role in retaining the stability between beneficial as well as non-beneficial traits via signaling components ETR1, EIN2 and EIN2/EIL1 in a $P$. indica mutualism with plant's roots (Camehl et al., 2010). In another study, the P. indica induced methionine synthase activity was reported to facilitate methionine cycle of ethylene biosynthetic pathway (PeškanBerghöfer et al., 2004) during its colonization with plant roots via immuno suppression explaining surprisingly broad host range of the fungus (Jacobs et al., 2011). In a DNA microarray study, expression analysis of gene of $P$. indica colonized $H$. vulgare roots depicted differentially expressed ethylene related genes (Schäfer et al., 2009). Ethylene was reported to positively modulate the $P$. indica-plant interaction via signal molecules of fungi as well as plant receptors at the root cells surface after landing the fungal spores to attain the desired compatibility. Interestingly, ethylene signal magnitude also plays an important part in the colonization of plant roots by $P$. indica; where, ethylene signaling either inhibits or promotes the growth of hyphae depending upon magnitude of signaling (Camehl et al., 2013). It is now clear that to establish the symbiosis, ethylene signaling network requires definite biochemical or genetic actions to sustain a communication across the symbionts as well as host plants to provide physiological benefits to each partner (Ansari et al., 2013).

\section{$P$. indica as a Regulator of Genes Involved in Plant Metabolism and Mineral Uptake}

Piriformospora indica interaction studies in Arabidopsis and $H$. vulgare have provided molecular basis of the beneficial plant-microbe interaction (Sherameti et al., 2005; Achatz et al.,
2010; Yadav et al., 2010; Ngwene et al., 2013; Pedersen et al., 2013). The fungus in a mutual interaction with plants has already been known to provide enhanced nitrate/nitrogen uptake (Sherameti et al., 2005; Yadav et al., 2010). The up-regulation of Nia2 gene of NR and SEX1 gene of starch degrading enzymes was reported to influence a substantial source and sink relation (Sherameti et al., 2005). The additional sinks were remained balanced via higher rates of $\mathrm{CO}_{2}$ assimilation in $H$. vulgare plants colonized by $P$. indica with respect to the subsequent controls (Achatz et al., 2010). The elevated N, P and K endogenous content were reported in chickpea as well as black lentil plants colonized with $P$. indica (Nautiyal et al., 2010). In contrast, $\mathrm{Fe}$ and $\mathrm{Cu}$ deficiencies in sugar cane plants were surpassed if inoculated with $P$. indica (Gosal et al., 2011). The expression profile of receptor kinase in roots of Arabidopsis and enhanced uptake of radio-labeled $\mathrm{P}$ was observed after colonization of the endophytic fungus (Shahollari et al., 2005). P. indica-mediated P-uptake and transport were evidenced to improve plant growth and development via their impact on various regulatory, structural and addition to energy transfer processes (Kumar et al., 2011). Further, reduced endogenous content of phosphate in $Z$. mays plants were detected upon its colonization by $P$. indica mutant where, a phosphate transporter was knocked out (Yadav et al., 2010; Ngwene et al., 2013).

\section{P. indica as a Regulator of Genes Involved in Plant Stress Resistance and Defense}

Piriformospora indica colonization provides certain benefits to the host plant such as tolerance to high salt and drought, resistance against heavy metal toxicity and protection from pathogen attack (Unnikumar et al., 2013). P. indica colonized T. aestivum showed an optimum growth under rising concentrations of salt (Zarea et al., 2012). Plants such as Arabidopsis, Chinese cabbage and strawberry were recovered from drought stress when pre-inoculated with endophyte P. indica (Sherameti et al., 2008; Husaini et al., 2012). The expression profile of the drought responsive genes such as DREB2A, ANAC072, CBL1 in addition to RD29A were positively modulated in the leaves of $P$. indica-colonized plants under drought stress exposure (Sun et al., 2010). The drought tolerance was exhibited as higher endogenous proline level which in turn led to increased tolerance to osmotic stress in endophyte colonized plants when compared to non-colonized one (Zarea et al., 2012). H. vulgare plants pre-inoculated with $P$. indica displayed augmented profile of enzymatic and non-enzymatic antioxidants levels resulting increased tolerant to drought and high salt (Baltruschat et al., 2008). The increased antioxidants level was evident by reduced dehydroascorbate level via dehydroascorbate conversion to ascorbate and elevated glutathione level (Waller et al., 2005). The stress tolerance response of $P$. indicacolonized plants was found to be associated with burst accumulation of plastid-localized proteins such as $\mathrm{Ca}^{2+}$ sensing regulator (CAS) in the leaves of colonized plants (Sun et al., 2010). The use of $P$. indica was found to be 
more effective in improving salt stress tolerance in crop plants that consequently has opened an innovative and promising application of this fungus in sustainable agriculture, especially in the areas affected by salinity (Zarea et al., 2013). The differential expression profile of abiotic stress responsive genes putatively engaged in various stress response in $P$. indica-colonized plants is required for in-depth interpretation of the mechanism functions via induction of osmoprotectants and heat shock proteins in plant cell (Waller et al., 2005; Vadassery et al., 2009; Zarea et al., 2013).

In $P$. indica-inoculated host plants, pathogenesis related $P R$ genes, JA (VSP, PDF1.2, LOX2) and ethylene ET (ERF1) signaling genes were reported up-regulated in response to pathogen attack (Camehl et al., 2010; Molitor et al., 2011). P. indica mediated $H$. vulgare plant protection was first observed against F. culmorum and B. graminis in root and shoot part, respectively (Waller et al., 2005). Enhanced antioxidant defense system has been evidenced as a major factor involved in $P$. indica colonization mediated beneficial effects in $H$. vulgare, T. aestivum and Z. mays roots (Waller et al., 2005; Serfling et al., 2007; Kumar et al., 2009). It is also evident from mutant study that not nuclear but the cytosolic non-expressor of PR-genes 1 (NPR1) form is required by the fungus in order to induce systemic resistance (Stein et al., 2008). For this reason, the mechanisms involved in $P$. indica-induced resistance in plants is more or less similar to systemic resistance induced by plant growthpromoting rhizobacteria-colonized plants (Van Wees et al., 2008). The endophyte provides inducing systemic resistance against pathogenic fungi and also protects the plant against damages caused by the invading pathogens via direct antagonism (Johnson et al., 2013).

\section{CONCLUSION AND FUTURE PERSPECTIVES}

Piriformospora indica is a mycorrhiza like endophytic fungus which exhibits its versatility for colonizing the plant species with direct manipulation of plant hormone signaling and induces both local and systemic resistance to several fungal and viral plant diseases through signal transduction. $P$. indica is multifunctional in providing its services such as nutrient uptake, disease resistance, stress tolerance and growth-promotion (Unnikumar et al., 2013). This fungus has become an outstanding tool for biological hardening during transplantation of micro-propagated plantlets. $P$. indica-infestation in a number of medicinal plants has been reported to stimulate the synthesis of valuable secondary metabolites (Bagde et al., 2010a; Prasad et al., 2013), therefore possess commercial and biotechnological importance. The comparison of the $P$. indica genome with other fungi has revealed its classical features related with biotrophism as well

\section{REFERENCES}

Abadi, V. A. J. M., and Sepehri, M. (2015). Effect of Piriformospora indica and Azotobacter chroococcum on mitigation of zinc deficiency stress in wheat (Triticum aestivum L.). Symbiosis 1-11. doi: 10.1007/s13199-015-0361-z as saprotrophism (Deshmukh et al., 2006; Qiang et al., 2011). $P$. indica has also evolved highly effective colonization strategies in diverse plant species (Deshmukh et al., 2006; Schäfer and Kogel, 2009; Qiang et al., 2011). The significant number of reports accumulated during last one decade has confirmed the $P$. indica-mediated improvements in the growth and yield of various plants, which includes crop plants, horticultural and medicinal plants. These reports also support the role of $P$. indica in crop tolerance to a number of abiotic as well as biotic stresses. Therefore, $P$. indica can be used as: (i) bio-control agent and plant stress response mediator, (ii) regulator of genes involved in metabolism and mineral uptake, and (iii) regulator of genes involved in resistance and defense of plants. It needs elaboration of a few studies done on the role of nano(bio)technology in acheiving major insights into and benefits of plant-interaction with fungi/P. indica (Suman et al., 2010; Menezes et al., 2015; Pandey et al., 2015; Prasad et al., 2015b). Furthermore, in order to commercially exploit the potentialities of $P$. indica in improving biotic and abiotic stress tolerance in crop plants, in addition to establishing $P$. indica inoculum production conditions and its formulation and stability; and exploring the persistence of the fungus in the environment, the future research should focus on revealing: (i) the mechanisms underpinning broad compatibility in root symbiosis, (ii) functional analyses of the effector-like proteins, (iii) symbiosis determinants, and (iv) identification of novel symbiosis/pathogenicity genes.

\section{AUTHOR CONTRIBUTIONS}

SSG, RG, AJ, AV, NAA, NT, and EP developed the idea and wrote/finalized the MS. SSG, DT, MA, NAA, EP, RP, KKS, MWA, AAA made the figures and developed table and helped in writing. All authors read and approved the approved the final manuscript.

\section{ACKNOWLEDGMENTS}

Work on plant-fungal interactions, plant abiotic stress tolerance in SSG and NT's laboratory is supported by University Grants Commission (UGC), Department of Science and Technology (DST) and Department of Biotechnology (DBT), Government of India, respectively. NAA gratefully acknowledges the partial financial supports received from FCT (Government of Portugal) through contract (SFRH/BPD/84671/2012), and NAA and EP also thanks for financial supports to the Aveiro University Research Institute/CESAM (UID/AMB/50017/2013), and to FCT/MEC through national funds, and the co-funding by the FEDER, within the PT2020 Partnership Agreement and Compete 2020 .

Achatz, B., Ruden, S. V., Andrade, D., Neumann, E., Kuhnemann, J. P., Kogel, K. H., et al. (2010). Root colonization by Piriformospora indica enhances grain yield in barley under diverse nutrient regimes by accelerating plant development. Plant Soil 333, 59-70. doi: 10.1007/s11104-0100319-0 
Adya, A. K., Gautam, A., Zhang, L., and Varma, A. (2013). "Characterization of Piriformospora indica culture filtrate," in Sebacinales - Forms, Functions and Biotechnological Applications, Soil Biology Series No. 33, eds A. Varma, G. Kost, and R. Oelmuller (Berlin: Springer-Verlag), 345-375.

Ahlawat, A., Saxena, A., and Abdin, M. Z. (2015). Piriformospora indica elicitation of withaferin A biosynthesis and biomass accumulation in cell suspension cultures of Withania somnifera. Symbiosis 1-10.

Akum, F. N., Steinbrenner, J., Biedenkopf, D., Imani, J., and Kogel, K. H. (2015). The Piriformospora indica effector PIIN_08944 promotes the mutualistic Sebacinalean symbiosis. Front. Plant Sci. 6:906. doi: 10.3389/fpls.2015.00906

Al-Absi, K., and Al-Ameiri, N. (2015). Physiological responses of tomato to inoculation with Piriformospora indica under osmotic stress and chloride toxicity. Intl. J. Agric. Forest 5, 226-239.

Alikhani, M., Khatabi, B., Sepehri, M., Nekouei, M. K., Mardi, M., and Salekdeh, G. H. (2013). A proteomics approach to study the molecular basis of enhanced salt tolerance in barley (Hordeum vulgare L.) conferred by the root mutualistic fungus Piriformospora indica. Mol. Biosys. 9, 1498-1510. doi: $10.1039 / \mathrm{c} 3 \mathrm{mb} 70069 \mathrm{k}$

Anith, K. N., Sreekumar, A., and Sreekumar, J. (2015). The growth of tomato seedlings inoculated with co-cultivated Piriformospora indica and Bacillus pumilus. Symbiosis 65, 9-16. doi: 10.1007/s13199-015-0313-7

Ansari, M. W., Bains, G., Shukla, A., Pant, R. C., and Tuteja, N. (2013). Low temperature stress ethylene and not Fusarium might be responsible for mango malformation. Plant Physiol. Biochem. 69, 34-38. doi: 10.1016/j.plaphy.2013.04.019

Ansari, M. W., Gill, S. S., and Tuteja, N. (2014). Piriformospora indica a powerful tool for crop improvement. Proc. Indian Natl. Sci. Acad. 80, 317-324. doi: 10.16943/ptinsa/2014/v80i2/55109

Apel, K., and Hirt, H. (2004). Reactive oxygen species: metabolism, oxidative stress, and signal transduction. Annu. Rev. Plant Biol. 55, 373-399. doi: 10.1146/annurev.arplant.55.031903.141701

Bagde, U. S., Prasad, R., and Varma, A. (2010a). Interaction of Piriformospora indica with medicinal plants and of economic importance. Afr. J. Biotechnol. 9, 9214-9226.

Bagde, U. S., Prasad, R., and Varma, A. (2010b). Mass cultivation of Piriformospora indica in New Brunswick Fermenter and its formulation as biofertilizer. Asian J. Microbial. Biotechnol. Environ. Sci 12, 911-916.

Bagde, U. S., Prasad, R., and Varma, A. (2011). Influence of culture filtrate of Piriformospora indica on growth and yield of seed oil in Helianthus annus. Symbiosis 53, 83-88. doi: 10.1007/s13199-011-0114-6

Bagde, U. S., Prasad, R., and Varma, A. (2014). Impact of culture filtrate of Piriformospora indica on biomass and biosynthesis of active ingredient aristolochic acid in Aristolochia elegans Mart. Intl. J. Biol. 1, 29-37.

Baishya, D., Deka, P., and Kalita, M. (2015). In vitro co-cultivation of Piriformospora indica filtrate for improve biomass productivity in Artemisia annua (L.). Symbiosis 66, 1-10. doi: 10.1007/s13199-015-0331-5

Bajaj, R., Agarwal, A., Rajpal, K., Asthana, S., Kumar, R., Prasad, R., et al. (2014). Co-cultivation of Curcuma longa with Piriformospora indica enhances the yield and active ingredients. Am. J. Curr. Microbiol. 2, 6-17.

Balemi, T., and Negisho, K. (2012). Management of soil phosphorus and plant adaptation mechanisms to phosphorus stress for sustainable crop production: a review. J. Soil Sci. Plant Nutr. 12, 547-562.

Baltruschat, H., Fodor, J., Harrach, B. D., Niemczyk, E., Barna, B., Gullner, G., et al. (2008). Salt tolerance of barley induced by the root endophyte Piriform ospora indica is associated with a strong increase in antioxidants. New Phytol. 180, 501-510. doi: 10.1111/j.1469-8137.2008.02583.x

Barazani, O., and Baldwin, I. T. (2013). "A mixed bag: the plant growthpromoting Sebacina vermifera impairs defense mechanisms against herbivores," in Sebacinales - Forms, Functions and Biotechnological Applications, Soil Biology Series No. 33, eds A. Varma, G. Kost, and R. Oelmuller (Berlin: Springer-Verlag), 251-262.

Barazani, O., Benderoth, M., Groten, K., Kuhlemeier, C., and Baldwin, I. T. (2005). Piriformospora indica and Sebacina vermifera increase growth performance at the expense of herbivore resistance in Nicotiana attenuata. Oecologia 146, 234-243. doi: 10.1007/s00442-005-0193-2

Barazani, O., Von Dahl, C. C., and Baldwin, I. T. (2007). Sebacina vermifera promotes the growth and fitness of Nicotiana attenuata by inhibiting ethylene signaling. Plant Physiol. 144, 1223-1232. doi: 10.1104/pp.107.097543
Becquer, A., Trap, J., Irshad, U., Ali, M. A., and Claude, P. (2014). From soil to plant, the journey of $\mathrm{P}$ through trophic relationships and ectomycorrhizal association. Front. Plant Sci. 5:548. doi: 10.3389/fpls.2014.00548

Bhuyan, S. K., Bandyopadhyay, P., Kumar, P., Kumar, P., Mishra, D., Prasad, R., et al. (2015). Interaction of Piriformospora indica with Azotobacter chroococcum. Sci. Rep. 5:13911. doi: 10.1038/srep13911

Camehl, I., and Oelmüller, R. (2010). Do ethylene response factors-9 and 14 repress PR gene expression in the interaction between Piriformospora indica and Arabidopsis? Plant Signal. Behav. 5, 932-936. doi: 10.4161/psb.5.8. 12036

Camehl, I., Sherameti, I., Seebald, E., Michal, J., and Oelmüller, R. (2013). "Role of defense compounds in the beneficial interaction between Arabidopsis thaliana and Piriformospora indica," in Sebacinales - Forms, Functions and Biotechnological Applications, Soil Biology Series No. 33, eds A. Varma, G. Kost, and R. Oelmuller (Berlin: Springer-Verlag), 239-250.

Camehl, I., Sherameti, I., Venus, Y., Bethke, G., Varma, A., Lee, J., et al. (2010). Ethylene signalling and ethylene-targeted transcription factors are required to balance beneficial and nonbeneficial traits in the symbiosis between the endophytic fungus Piriformospora indica and Arabidopsis thaliana. New Phytol. 185, 1062-1073. doi: 10.1111/j.1469-8137.2009.03149.x

Das, A., Kamal, S., Shakil Najam, A., Sherameti, I., Oelmuller, R., Dua, M., et al. (2012). The root endophyte fungus Piriformospora indica leads to early flowering, higher biomass and altered secondary metabolites of the medicinal plant, Coleus forskohlii. Plant Signal. Behav. 7, 1-10. doi: 10.4161/psb.7.1.18472

Das, A., Prasad, R., Srivastava, R. B., Deshmukh, S., Rai, M. K., and Varma, A. (2013). "Cocultivation of Piriformospora indica with medicinal plants: case studies," in Sebacinales - Forms, Functions and Biotechnological Applications, Soil Biology Series No. 33, eds A. Varma, G. Kost, and R. Oelmuller (Berlin: Springer-Verlag), 149-172.

Das, A., Tripathi, S., and Varma, A. (2014). In vitro plant development and root colonization of Coleus forskohlii by Piriformospora indica. World J. Microbiol. Biotechnol. 30, 1075-1084. doi: 10.1007/s11274-013-1526-7

De Backer, M. D., Raponi, M., and Arndt, G. M. (2002). RNA-mediated gene silencing in non- pathogenic and pathogenic fungi. Curr. Opin. Microbiol. 5, 323-329. doi: 10.1016/S1369-5274(02)00319-3

Deshmukh, S., Hückelhoven, R., Schäfer, P., Imani, J., Sharma, M., Weiss, M., et al. (2006). The root endophytic fungus Piriformospora indica requires host cell death for proliferation during mutualistic symbiosis with barley. Proc. Natl. Acad. Sci. U.S.A. 103, 18450-18457. doi: 10.1073/pnas.0605697103

Deshmukh, S., Hueckelhoven, R., Schaefer, P., Imani, J., Sharma, M., Weiss, M., et al. (2007). Piriformospora indica protects barley from root rot caused by Fusarium graminearum. J. Plant Dis. Protect. 114, 263-268.

Deshmukh, S. D., and Kogel, K. H. (2007). Piriformospora indica protects barley from root rot caused by Fusarium graminearum. J. Plant Dis. Protect. 114, 263-268.

Dolatabadi, H. K., Goltapeh, E. M., Mohammadi, N., Rabiey, M., Rohani, N., and Varma, A. (2012). Biocontrol potential of root endophytic fungi and Trichoderma species against Fusarium wilt of lentil under in vitro and greenhouse conditions. J. Agric. Sci. Technol. 14, 407-420.

Esseling, J. J., and Emons, A. M. (2004). Dissection of Nod fact or signalling in legumes: cell biology, mutants and pharmacological approaches. J. Microscopy 214, 104-113. doi: 10.1111/j.0022-2720.2004.01322.x

Fakhro, A., Andrade-Linares, D. R., von Bargen, S., Bandte, M., Buttner, C., Grosch, R., et al. (2010). Impact of Piriformospora indica on tomato growth and on interaction with fungal and viral pathogens. Mycorrhiza 20, 191-200. doi: 10.1007/s00572-009-0279-5

Foyer, C. H., and Shigeoka, S. (2011). Understanding oxidative stress and antioxidant functions to enhance photosynthesis. Plant Physiol. 155, 93-100. doi: $10.1104 /$ pp.110.166181

Ghabooli, M. (2014). Effect of Piriformospora indica inoculation on some physiological traits of barley (Hordeum vulgare) under salt stress. Chem. Nat. Compd. 50, 1082-1087. doi: 10.1007/s10600-014-1164-9

Ghabooli, M., Khatabi, B., Ahmadi, F. S., Sepehri, M., Mirzaei, M., Amirkhani, A., et al. (2013). Proteomics study reveals the molecular mechanisms underlying water stress tolerance induced by Piriformospora indica in barley. J. Proteomics 94, 289-301. doi: 10.1016/j.jprot.2013.09.017

Ghahfarokhi, R. M., and Goltapeh, M. E. (2010). Potential of the root endophytic fungus Piriformospora indica; Sebacina vermifera and Trichoderma species in 
biocontrol of take-all disease of wheat Gaeumannomyces graminis var. tritici in vitro. J. Agric. Technol. 6, 11-18.

Ghanem, G., Ewald, A., Zerche, S., and Hennig, F. (2014). Effect of root colonization with Piriformospora indica and phosphate availability on the growth and reproductive biology of a Cyclamen persicum cultivar. Sci. Hortic. 172, 233-241. doi: 10.1016/j.scienta.2014.04.022

Gosal, S. K., Karlupia, A., Gosal, S. S., Chhibba, I. M., and Varma, A. (2010). Biotization with Piriformospora indica and Pseudomonas fluorescens improves survival rate, nutrient acquisition, field performance and saponin content of micropropagated Chlorophytum sp. Indian J. Biotechnol. 9, 289-297.

Gosal, S. K., Sharma, M., Gosal, S. S., Chhibba, I. M., Bhatnagar, K., and Varma, A. (2011). Biohardening with Piriformospora indica improves survival rate, growth, iron uptake and cane yield of micropropagated sugarcane. Int. Sugar J. 113, 382-388.

Guescini, M., Pierleoni, R., Palma, F., Zeppa, S., Vallorani, L., Potenza, L., et al. (2003). Characterization of the Tuber borchiinitrate reductase gene and its role in ectomycorrhizae. Mol. Genet. Genomics. 269, 807-816. doi: 10.1007/s00438003-0894-3

Hamilton, C. E., Gundel, P. E., Helander, M., and Saikkonen, K. (2012). Endophytic mediation of reactive oxygen species and antioxidant activity in plants: a review. Fungal Divers. 54, 1-10. doi: 10.1007/s13225-012-0158-9

Harrach, B. D., Baltruschat, H., Barna, B., Fodor, J. K., and Ogel, K. H. (2013). The mutualistic fungus Piriformosporaindica protects barley roots from a loss of antioxidant capacity caused by the necrotrophic pathogen Fusariumculmorum. Mol. Plant Microbe Interact 26, 599-605. doi: 10.1094/MPMI-09-12-0216-R

Harrison, M. J. (2005). Signaling in the arbuscular mycorrhizal symbiosis. Annu. Rev. Microbiol. 59, 19-42. doi: 10.1146/annurev.micro.58.030603.123749

Hayat, R., Ali, S., Amara, U., Khalid, R., and Ahmed, I. (2010). Soil beneficial bacteria and their role in plant growth promotion: a review. Ann. Microbiol. 60, 579-598. doi: 10.1007/s13213-010-0117-1

Heath, M. C. (1998). Apoptosis, programmed cell death and the hypersensitive response. Eur. J. Plant Pathol. 104, 117-124. doi: 10.1023/A:1008645520976

Heath, M. C. (2000). Hypersensitive response-related death. Plant Mol. Biol. 44, 312-334. doi: 10.1023/A:1026592509060

Hilbert, M., Voll, L. M., Ding, Y., Hofmann, J., Sharma, M., and Zuccaro, A. (2012). Indole derivative production by the root endophyte Piriformospora indica is not required for growth promotion but for biotrophic colonization of barley roots. New Phytol. 196, 520-534. doi: 10.1111/j.1469-8137.2012.04275.x

Hoeberichts, F. A., and Woltering, E. J. (2003). Multiple mediators of plant programmed cell death: interplay of conserved cell death mechanisms and plant-specific regulators. Bioessays 25, 47-57. doi: 10.1002/bies.10175

Hückelhoven, R. (2004). BAX Inhibitor-1, an ancient cell death suppressor in animals and plants with prokaryotic relatives. Apoptosis 9, 299-307. doi: 10.1023/B:APPT.0000025806.71000.1c

Hui, F., Liu, J., Gao, Q., and Lou, B. (2015). Piriformospora indica confers cadmium tolerance in Nicotiana tabacum. J. Environ. Sci. 37, 184-191. doi: 10.1016/j.jes.2015.06.005

Husaini, A. M., Abdin, M. Z., Khan, S., Xu, Y. W., Aquil, S., and Anis, M. (2012). Modifying strawberry for better adaptability to adverse impact of climate change. Curr. Sci. 102, 1660-1673.

Jacobs, S., Zechmann, B., Molitor, A., Trujillo, M., Petutschnig, E., Lipka, V., et al. (2011). Broad-spectrum suppression of innate immunity is required for colonization of Arabidopsis roots by the fungus Piriformospora indica. Plant Physiol. 156, 726-740. doi: 10.1104/pp.111.176446

Jogawat, A., Saha, S., Bakshi, M., Dayaman, V., Kumar, M., Dua, M., et al. (2013). Piriformospora indica rescues growth diminution of rice seedlings during high salt stress. Plant Signal. Behav. 8, e26891. doi: 10.4161/psb.26891

Johnson, J. M., Sherameti, I., Nongbri, P. L., and Oelmüller, R. (2013). "Standardized conditions to study beneficial and nonbeneficial traits in the Piriformospora indica/Arabidopsis thaliana interaction," in Sebacinales - Forms, Functions and Biotechnological Applications, Soil Biology Series No. 33, eds A. Varma, G. Kost, and R. Oelmuller (Berlin: Springer-Verlag), 325-343.

Johri, A. K., Oelmüller, R., Dua, M., Yadav, V., Kumar, M., Tuteja, N., et al. (2015). Fungal association and utilization of phosphate by plants: success, limitations, and future prospects. Front. Microbiol. 6:984. doi: 10.3389/fmicb.2015.00984

Karandashov, V., Nagy, R., Wegmuller, S., Amrhein, N., and Bucher, M. (2004). Evolutionary conservation of a phosphate transporter in the arbuscular mycorrhizal symbiosis. Proc. Natl. Acad. Sci. U.S.A. 101, 6285-6290. doi: 10.1073/pnas.0306074101

Keurentjes, J. J. B., Angenent, G. C., Dicke, M., van der Putten, W. H., de Ruiter, P. C., Struik, P. C., et al. (2011). Redefining plant systems biology: from cell to ecosystem. Trend Plant Sci. 16, 183-190. doi: 10.1016/j.tplants.2010.12.002

Khatabi, B. (2009). Molecular Studies on Compatibility in the Mutualistic Plant Root-Piriformospora indica Interaction. M.Sc. Dissertation, Naturwissenschaftlichen Fachbereiche, Justus-Liebig-Universität Gießen

Khatabi, B., Molitor, A., Lindermayr, C., Pfiffi, S., Durner, J., Wettstein, D. V., et al. (2012). Ethylene supports colonization of plant roots by the mutualistic fungus Piriformospora indica. PLoS ONE 7:e35502.

Kloppholz, S., Kuhn, H., and Requena, N. (2011). A secreted fungal effector of Glomus intraradices promotes symbiotic biotrophy. Curr. Biol. 21, 1204-1209. doi: 10.1016/j.cub.2011.06.044

Knecht, K., Seyffarth, M., Desel, C., Thurau, T., Sherameti, I., Lou, B., et al. (2010). Expression of $B v G L P-1$ encoding a germin-like protein from sugar beet in Arabidopsis thaliana leads to resistance against phytopathogenic fungi. Mol. Plant Microbe Interact. 23, 446-457. doi: 10.1094/MPMI-23-4-0446

Kumar, M., Yadav, V., Singh, A., Tuteja, N., and Johri, A. K. (2011). Piriformospora indica enhances plant growth by transferring phosphate. Plant Signal. Behav. 6, 723-725. doi: 10.4161/psb.6.5.15106

Kumar, M., Yadav, V., Tuteja, N., and Johri, A. K. (2009). Antioxidant enzyme activities in maize plants colonized with Piriformospora indica. Microbiology 155, 780-790. doi: 10.1099/mic.0.019869-0

Kumar, P., Chaturvedi, R., Sundar, D., and Bisaria, V. S. (2015). Piriformospora indica enhances the production of pentacyclic triterpenoids in Lantana camara L. suspension cultures. Plant Cell Tissue Organ Cult. 1-7. doi: 10.1007/s11240015-0924-y

Kumar, V., Sahai, V., and Bisaria, V. S. (2013). "Effect of Piriformospora indica on enhanced biosynthesis of anticancer drug, podophyllotoxin in plant cell cultures of Linum album," in Sebacinales - Forms, Functions and Biotechnological Applications, Soil Biology Series No. 33, eds A. Varma, G. Kost, and R. Oelmuller (Berlin: Springer-Verlag), 119-137.

Lam, E. (2004). Controlled cell death, plant survival and development. Nat. Rev. Mol. Cell Biol. 5, 305-315. doi: 10.1038/nrm1358

Lamb, C., and Dixon, R. A. (1997). The oxidative burst in plant disease resistance. Annu. Rev. Plant Physiol. Plant Mol. Biol. 48, 251-275. doi: 10.1146/annurev.arplant.48.1.251

Lee, Y. C., Johnson, J. M., Chien, C. T., Sun, C., Cai, D. G., Lou, B. G., et al. (2011). Growth promotion of Chinese cabbage and Arabidopsis by Piriformospora indica is not stimulated by mycelium-synthesized auxin. Mol. Plant Microbe Interact. 24, 421-431. doi: 10.1094/MPMI-05-10-0110

Lum, M. R., and Hirsch, A. M. (2003). Roots and their symbiotic microbes: strategies to obtain nitrogen and phosphorous in a nutrient-limiting environment. J. Plant Growth Regul. 21, 368-382. doi: 10.1007/s00344-0030003-1

Maillet, F., Poinsot, V., André, O., Puech-Pages, V., Haouy, A., Gueunier, M., et al. (2011). Fungal lipochitooligosaccharide symbiotic signals in arbuscular mycorrhiza. Nature 469, 58-63. doi: 10.1038/nature09622

Maldonado-Mendoza, I. E., Dewbre, G. R., and Harrison, M. J. (2001). A phosphate transporter gene from the extra-radical mycelium of an arbuscular mycorrhizal fungus Glomus intraradices is regulated in response to phosphate in the environment. Mol. Plant Microbe Interact. 14, 1140-1148. doi: 10.1094/MPMI.2001.14.10.1140

Malla, R., and Pokhare, S. (2008). Antifungal factor produced by Pseudomonas fluorescens against an endophytic fungus. Nepal J. Sci. Tech. 9, 65-71.

Matsushima, R., Fukao, Y., Nishimura, M., and Hara-Nishimura, I. (2004). NAI1 gene that encodes a basic-helix-loop-helix-type putative transcription factor that regulates the formation of a novel ER-derived structure, the ER body. Plant Cell 16, 1536-1549. doi: 10.1105/tpc.021154

McAinsh, M. R., and Pittman, J. K. (2009). Shaping the calcium signature. New Phytol. 181, 275-294. doi: 10.1111/j.1469-8137.2008.02682.x

Menezes, R. C., Kai, M., Krause, K., Matthäus, C., Svatoš, A., Popp, J., et al. (2015). Monitoring metabolites from Schizophyllum commune interacting with Hypholoma fascicula recombining LESA-HR mass spectrometry and Raman microscopy. Anal. Bioanal. Chem. 407, 2273-2282. doi: 10.1007/s00216-0148383-6 
Molitor, A., Zajic, D., Voll, L., Pons-Kuehnemann, J., Samans, B., Kogel, K. H., et al. (2011). Barley leaf transcriptome and metabolite analysis reveals new aspects of compatibility and Piriformospora indica-mediated systemic induced resistance to powdery mildew. Mol. Plant Microbe Interact. 24, 1427-1439. doi: 10.1094/MPMI-06-11-0177

Murphy, B. R., Doohan, F. M., and Hodkinson, T. R. (2014). Yield increase induced by the fungal root endophyte Piriformospora indica in barley grown at low temperature is nutrient limited. Symbiosis 62, 29-39. doi: 10.1007/s13199-0140268-0

Nautiyal, C. S., Chauhan, P. S., DasGupta, S. M., Seem, K., Varma, A., and Staddon, W. J. (2010). Tripartite interactions among Paenibacillus lentimorbus NRRL B-30488, Piriformospora indica DSM 11827, and Cicer arietinum L. World J. Microbiol. Biot. 26, 1393-1399. doi: 10.1007/s11274-010-0312-Z

Nekrasov, V., Li, J., Batoux, M., Roux, M., Chu, Z. H., Lacombe, S., et al. (2009). Control of the pattern recognition receptor EFR by an ER protein complex in plant immunity. EMBO J. 28, 3428-3438. doi: 10.1038/emboj.2009.262

Ngwene, B., Andrade-Linares, D. R., and Franken, P. (2013). "Phosphate solubilization and plant growth promotion of the fungal root endophyte Piriformospora indica," in Endophytes for Plant Protection: The State of The Art, eds C. Schneider, C. Leifert, and F. Feldmann (Braunschweig: Deutsche Phytomedizinische Gesellschaft), 192-193.

Nitz, I., Berkefeld, H., Puzio, P. S., and Grundler, F. M. W. (2001). Pyk10, a seedling and root specific gene and promoter from Arabidopsis thaliana. Plant Sci. 161, 337-346. doi: 10.1016/S0168-9452(01)00412-5

Oelmüller, R., Shahollari, B., Peškan-Berghöfer, T., Trebicka, A., Giong, P. H., Sherameti, I., et al. (2004). Molecular analyses of the interaction between Arabidopsis roots and the growth-promoting fungus Piriformospora indica. Endocytobiosis Cell Res. 15, 504-517.

Oelmüller, R., Sherameti, I., Tripathi, S., and Varma, A. (2009). Piriformospora indica, a cultivable root endophyte with multiple biotechnological applications. Symbiosis 49, 1-17. doi: 10.1007/s13199-009-0009-y

Pandey, R., Paidi, S. K., Kang, J. W., Spegazzini, N., Dasari, R. R., Valdez, T. A., et al. (2015). Discerning the differential molecular pathology of proliferative middle ear lesions using Raman spectroscopy. Nat. Sci. Rep. 5:13305. doi: 10.1038/srep13305

Pedersen, B. P., Kumar, H., Waight, A. B., Risenmay, A. J., Roe-Zurz, Z., Chau, B. H., et al. (2013). Crystal structure of a eukaryotic phosphate transporter. Nature 496, 533-536. doi: 10.1038/nature12042

Peškan-Berghöfer, T., Shahollari, B., Giang, P. H., Hehl, S., Markert, C., Blanke, V., et al. (2004). Association of Piriformospora indica with Arabidopsis thaliana roots represents a novel system to study beneficial plant-microbe interactions and involves early plant protein modifications in the endoplasmatic reticulum and at the plasma membrane. Physiol. Plant 122, 465-477. doi: 10.1111/j.13993054.2004.00424.x

Pham, G. H., Kumari, R., Singh, A., Sachdev, M., Prasad, R., Kaldorf, M., et al. (2004). "Axenic cultures of Piriformospora indica," in Plant Surface Microbiology, eds A. Varma, K. Abbott, D. Werner, and R. Hampp (Berlin: Springer), 593-616.

Plett, J. M., Daguerre, Y., Wittulsky, S., Vayssières, A., Deveau, A., Melton, S. J., et al. (2014). Effector MiSSP7 of the mutualistic fungus Laccaria bicolor stabilizes the populus JAZ6 protein and represses jasmonic acid (JA) responsive genes. Proc. Natl. Acad. Sci. U.S.A. 111, 8299-8304. doi: 10.1073/pnas.1322671111

Plett, J. M., Kemppainen, M., Kale, S. D., Kohler, A., Legué, V., Brun, A., et al. (2011). A secreted effector protein of Laccaria bicolor is required for symbiosis development. Curr. Biol. 21, 1197-1203. doi: 10.1016/j.cub.2011.05.033

Porras-Alfaro, A., and Bayman, P. (2011). Hidden fungi, emergent properties: endophytes and microbiomes. Annu. Rev. Phytopathol. 49, 291-315. doi: 10.1146/annurev-phyto-080508-081831

Prasad, R. (2008). Studies on Interaction Between Symbiotic Fungus (Piriformospora indica), Rhizobacteria and Selected Plants. Ph.D. thesis, Merrut University, Meerut.

Prasad, R., Kamal, S., Sharma, P. K., Oelmueller, R., and Varma, A. (2013). Root endophyte Piriformospora indica DSM 11827 alters plants morphology, enhances biomass and antioxidant activity of medicinal plant Bacopa monniera. J. Basic Microbiol. 53, 1016-1024. doi: 10.1002/jobm.201200367

Prasad, R., Kumar, M., and Varma, A. (2015a). "Role of PGPR in soil fertility and plant health," in Plant Growth-Promoting Rhizobacteria and Medicinal Plants, eds D. Egamberdieva, S. Shrivastava, and A. Varma (Cham: Springer), 247-260.
Prasad, R., Pandey, R., and Barman, I. (2015b). Engineering tailored nanoparticles with microbes: quo vadis? Wiley Interdiscip. Rev. Nanomed. Nanobiotechnol. 8, 316-330. doi: 10.1002/wnan.1363

Prasad, R., Sharma, M., Kamal, S., Rai, M. K., Rawat, A. K. S., Pushpangdan, P., et al. (2008). "Interaction of Piriformospora indica with medicinal plants," in Mycorrhiza, ed. A. Varma (Berlin: Springer-Verlag), 655-678.

Qiang, X., Weiss, M., Kogel, K. H., and Schäfer, P. (2011). Piriformospora indica a mutualistic basidiomycete with an exceptionally large plant host range. Mol. Plant Pathol. 13, 508-518. doi: 10.1111/j.1364-3703.2011.00764.x

Qiang, X., Zechmann, B., Reitz, M. U., Kogel, K. H., and Schafer, P. (2012). The mutualistic fungus Piriformospora indica colonizes Arabidopsis roots by inducing an endoplasmic reticulum stress-triggered caspase-dependent cell death. Plant Cell 24, 794-809. doi: 10.1105/tpc.111.093260

Rabiey, M., Ullah, I., and Shaw, M. W. (2015). The endophytic fungus Piriformospora indica protects wheat from fusarium crown rot disease in simulated UK autumn conditions. Plant Pathol. 64, 1029-1040. doi: 10.1111/ppa.12335

Rai, M., Acharya, D., Singh, A., and Varma, A. (2001). Positive growth responses of the medicinal plants Spilanthes calva and Withania somnifera to inoculation by Piriformospora indica in a field trial. Mycorrhiza 11, 123-128. doi: 10.1007/s005720100115

Rai, M. K., Varma, A., and Pandey, A. K. (2004). Antifungal potential of Spilanthes calva after inoculation of Piriformospora indica. Mycoses 47, 479-481. doi: 10.1111/j.1439-0507.2004.01045.x

Rask, L., Andreasson, E., Ekbom, B., Eriksson, S., Pontoppidan, B., and Meijer, J. (2000). Myrosinase: gene family evolution and herbivore defense in Brassicaceae. Plant Mol. Biol. 42, 93-113. doi: 10.1023/A:1006380021658

Rausch, C., and Bucher, M. (2002). Molecular mechanisms of phosphate transport in plants. Planta 216, 23-37. doi: 10.1007/s00425-002-0921-3

Rodriguez, R. J., Redman, R. S., and Henson, J. M. (2004). The role of fungal symbioses in the adaptation of plants to high stress environments. Mitigation Adapt. Strategies Glob. Change 9, 261-272.

Rodriguez, R. J., White, J. F. Jr., Arnold, A. E., and Redman, R. S. (2009). Fungal endophytes: diversity and functional roles. New Phytol. 182, 314-330. doi: 10.1111/j.1469-8137.2009.02773.x

Roesti, D., Gaur, R., Johri, B. N., Imfeld, G., and Sharma, S. (2006). Plant growth stage, fertilizer management and bio-inoculation of arbuscular mycorrhizal fungi and plant growth promoting rhizobacteria affect the rhizobacterial community structure in rain-fed wheat fields. Soil Biol. Biochem. 38, 1111-1120. doi: 10.1016/j.soilbio.2005.09.010

Saijo, Y., Tintor, N., Lu, X., Rauf, P., Pajerowska-Mukhtar, K., Häweker, H., et al. (2009). Receptor quality control in the endoplasmic reticulum for plant innate immunity. EMBO J. 28, 3439-3449. doi: 10.1038/emboj.2009.263

Sanders, D., Pelloux, J., Brownlee, C., and Harper, J. F. (2002). Calcium at the crossroads of signaling. Plant Cell 14(Suppl.), 401-417.

Sarma, M. V. R. K., Kumar, V., Saharan, K., Srivastava, R., Sharma, A. K., Prakash, A., et al. (2011). Application of inorganic carrier-based formulations of fluorescent pseudomonads and Piriformospora indica on tomato plants and evaluation of their efficacy. J. Appl. Microbiol. 111, 456-466. doi: 10.1111/j.13652672.2011.05062.x

Satheesan, J., Narayanan, A. K., and Sakunthala, M. (2012). Induction of root colonization by Piriformospora indica leads to enhanced asiaticoside production in Centella asiatica. Mycorrhiza 22, 195-202. doi: 10.1007/s00572-0110394-y

Schäfer, P., Khatabi, B., and Kogel, K. H. (2007). Root cell death and systemic effects of Piriformospora indica: a study on mutualism. FEMS Microbiol. Lett. 275, 1-7. doi: 10.1111/j.1574-6968.2007.00848.x

Schäfer, P., and Kogel, K. H. (2009). "The Sebacinoid fungus Piriformospora indica, an orchid mycorrhiza which may increase host plant reproduction and fitness," in Plant Relationships, ed. H. Deising (Berlin: Springer-Verlag), 99-112.

Schäfer, P., Pfiffi, S., Voll, L. M., Zajic, D., Chandler, P. M., Waller, F., et al. (2009). Manipulation of plant innate immunity and gibberellin as factor of compatibility in the mutualistic association of barley roots with Piriformospora indica. Plant J. 59, 461-474. doi: 10.1111/j.1365-313X.2009.03887.x

Schuck, S., Camehl, I., Gilardoni, P. A., Oelmüller, R., Baldwin, I. T., and Bonaventure, G. (2012). HSPRO controls early Nicotiana attenuata seedling growth during interaction with the fungus Piriformospora indica. Plant Physiol. 160, 929-943. doi: 10.1104/pp.112.203976 
Serfling, A., Wirsel, S. G., Lind, V., and Deising, H. B. (2007). Performance of the biocontrol fungus Piriformospora indica on wheat under greenhouse and field conditions. Phytopathology 97, 523-531. doi: 10.1094/PHYTO-97-4-0523

Shahabivand, S., Maivan, H. Z., Goltapeh, E. M., Sharifi, M., and Aliloo, A. A. (2012). The effects of root endophyte and arbuscular mycorrhizal fungi on growth and cadmium accumulation in wheat under cadmium toxicity. Plant Physiol. Biochem. 60, 53-58. doi: 10.1016/j.plaphy.2012.07.018

Shahollari, B., Vadassery, J., Varma, A., and Oelmüller, R. (2007). A leucine-rich repeat protein is required for growth promotion and enhanced seed production mediated by the endophytic fungus Piriformospora indica in Arabidopsis thaliana. Plant J. 50, 1-13. doi: 10.1111/j.1365-313X.2007.03028.x

Shahollari, B., Varma, A., and Oelmuller, R. (2005). Expression of a receptor kinase in Arabidopsis roots is stimulated by the basidiomycete Piriformospora indica and the protein accumulates in Triton X-100 insoluble plasma membrane microdomains. J. Plant Physiol. 162, 945-958. doi: 10.1016/j.jplph.2004.08.012

Sharafzadeh, S. (2012). Effects of ethylene on growth and active substances of medicinal plants. Int. J. Pharma Bio Sci. 3, 465-469.

Sharma, G., and Agarwal, V. (2013). Marked enhancement in the artemisinin content and biomass productivity in Artemisia annua L. shoots co-cultivated with Piriformospora indica. World J. Microbiol. Biotechnol. 29, 1133-1138. doi: 10.1007/s11274-013-1263-y

Sharma, M., Schmid, M., Rothballer, M., Hause, G., Zuccaro, A., Imani, J., et al. (2008). Detection and identification of bacteria intimately associated with fungi of the order Sebacinales. Cell Microbiol. 10, 2235-2246. doi: 10.1111/j.14625822.2008.01202.x

Sharma, P., Kharkwal, A. C., Abdin, M. Z., and Varma, A. (2014). Piriformospora indica improves micropropagation, growth and phytochemical content of Aloe vera L. plants. Symbiosis 64, 11-23. doi: 10.1007/s13199-014-0298-7

Shen, H., Ye, W., Hong, L., Huang, H., Wang, Z., Deng, X., et al. (2006). Progress in parasitic plant biology: host selection and nutrient transfer. Plant Biol. 8, 175-185. doi: 10.1055/s-2006-923796

Sherameti, I., Shahollari, B., Venus, Y., Altschmied, L., Varma, A., and Oelmuller, R. (2005). The endophytic fungus Piriformospora indica stimulates the expression of nitrate reductase and the starch-degrading enzyme glucan-water dikinase in tobacco and Arabidopsis roots through a homeodomain transcription factor that binds to a conserved motif in their promoters. J. Biol. Chem. 280, 2624126247.

Sherameti, I., Tripathi, S., Varma, A., and Oelmuller, R. (2008). The rootcolonizing endophyte Pirifomospora indica confers drought tolerance in Arabidopsis by stimulating the expression of drought stress related genes in leaves. Mol. Plant Microbe Interact. 21, 799-807. doi: 10.1094/MPMI-21-6-0799

Shoresh, M., Mastouri, F., and Harman, G. E. (2010). Induced systemic resistance and plant responses to fungal biocontrol agents. Annu. Rev. Phytopathol. 48, 21-43. doi: 10.1146/annurev-phyto-073009-114450

Singh, A., Sharma, J., Rexer, K. H., and Varma, A. (2000). Plant productivity determinants beyond minerals, water and light. Piriformospora indica: a revolutionary plant growth promoting fungus. Curr. Sci. 79, 101-106.

Singh, A., Singh, A., Kumari, M., Rai, M. K., and Varma, A. (2003). Biotechnological importance of Priformospora indicia - a novel symbiotic mycorrhiza-like fungus: an overview. Indian J. Biotechnol. 2, 65-75.

Singh, L. P., Gill, S. S., and Tuteja, N. (2011). Unraveling the role of fungal symbionts in plant abiotic stress tolerance. Plant Signal. Behav. 6, 175-191. doi: 10.4161/psb.6.2.14146

Sirrenberg, A., Göbel, C., Grond, S., Czempinski, N., Ratzinger, A., Karlovsky, P., et al. (2007). Piriformospora indica affects plant growth by auxin production. Physiol. Plant. 131, 581-589. doi: 10.1111/j.1399-3054.2007.00983.x

Stein, E., Molitor, A., Kogel, K. H., and Waller, F. (2008). Systemic resistance in Arabidopsis conferred by the mycorrhizal fungus Piriformospora indica requires jasmonic acid signaling and the cytoplasmic function of NPR1. Plant Cell Physiol. 49, 1747-1751. doi: 10.1093/pcp/pcn147

Stotz, H. U., Kroymann, J., and Mitchell-Olds, T. (1999). Plant-insect interactions. Curr. Opin. Plant Biol. 2, 268-272. doi: 10.1016/S1369-5266(99)80048-X

Stotz, H. U., Pittendrigh, B. R., Kroymann, J., Weniger, K., Fritsche, J., Bauke, A., et al. (2000). Induced plant defense responses against chewing insects. Ethylene signaling reduces resistance of Arabidopsis against cotton worm but not diamondback moth. Plant Physiol. 124, 1007-1017. doi: 10.1104/pp.124.3.1007

Suman, P. R., Jain, V. K., and Varma, A. (2010). Role of nanomaterials in symbiotic fungus growth enhancement. Curr. Sci. 99, 1189-1191.
Sun, C., Johnson, J. M., Cai, D., Sherameti, I., Oelmuller, R., and Lou, B. (2010). Piriformospora indica confers drought tolerance in Chinese cabbage leaves by stimulating antioxidant enzymes, the expression of drought-related genes and the plastid localized CAS protein. J. Plant Physiol. 167, 1009-1017. doi: 10.1016/j.jplph.2010.02.013

Sun, C., Shao, Y., Vahabi, K., Lu, J., Bhattacharya, S., Dong, S., et al. (2014). The beneficial fungus Piriformospora indica protects Arabidopsis from Verticillium dahliae infection by downregulation plant defense responses. BMC Plant Biol. 14:268. doi: 10.1186/s12870-014-0268-5

Thrall, P. H., Hochberg, M. E., Burdon, J. J., and Bever, J. D. (2007). Coevolution of symbiotic mutualists and parasites in a community context. Trend Ecol. Evol. 22, 120-126. doi: 10.1016/j.tree.2006.11.007

Tierens, K. F., Thomma, B. P., Brouwer, M., Schmidt, J., Kistner, K., Porzel, A., et al. (2001). Study of the role of antimicrobial glucosinolate-derived isothiocyanates in resistance of Arabidopsis to microbial pathogens. Plant Physiol. 125, 16881699. doi: $10.1104 /$ pp.125.4.1688

Trivedi, D. K., Bhatt, H., Pal, R., Johri, A. K., Tuteja, N., and Bhavesh, N. S. (2013). Sequence specific $1 \mathrm{H}, 13 \mathrm{C}$ and $15 \mathrm{~N}$ NMR assignments of cyclophilin A like protein from P. indica involved in salt tolerance. Biomol. NMR Assign. 7, 175-178. doi: 10.1007/s12104-012-9404-Z

Tsonev, T., and Lidon, F. J. C. (2012). Zinc in plants - an overview. Emir. J. Food Agric. 24, 322.

Tuladhar, R., Shrestha, J., Singh, A., and Varma, A. (2013). "Enhanced productivity associated with tripartite symbiosis between phaseolus, rhizobia, and Piriformospora indica: in presence of vermicompost," in Sebacinales Forms, Functions and Biotechnological Applications, Soil Biology Series No. 33, eds A. Varma, G. Kost, and R. Oelmuller (Berlin: Springer-Verlag), 191-199.

Unnikumar, K. R., Sowjanya, S. K., and Varma, A. (2013). Piriformospora indica: a versatile root endophytic symbiont. Symbiosis 60, 107-113. doi: 10.1007/s13199-013-0246-y

Upadhyaya, C. P., Gururani, M. A., Prasad, R., and Varma, A. (2013). A cell wall extract from Piriformospora indica promotes tuberization in potato (Solanum tuberosum L.) via enhanced expression of $\mathrm{Ca}+2$ signaling pathway and lipoxygenase gene. Appl. Biochem. Biotechnol. 170, 743-755. doi: 10.1007/s12010-013-0231-1

Vadassery, J., and Oelmüller, R. (2009). Calcium signaling in pathogenic and beneficial plant microbe interactions: what can we learn from the interaction between Piriformospora indica and Arabidopsis thaliana. Plant Signal. Behav. 4, 1024-1027. doi: 10.4161/psb.4.11.9800

Vadassery, J., Ranf, S., Drzewiecki, C., Mithöfer, A., Mazars, C., Scheel, D., et al. (2009). A cell wall extract from the endophytic fungus Piriformospora indica promotes growth of Arabidopsis seedlings and induces intracellular calcium elevation in roots. Plant J. 59, 193-206. doi: 10.1111/j.1365-313X.2009. 03867.x

Vadassery, J., Ritter, C., Venus, Y., Camehl, I., Varma, A., Shahollari, B., et al. (2008). The role of auxins and cytokinins in the mutualistic interaction between Arabidopsis and Piriformospora indica. Mol. Plant Microbe Interact. 21, 13711383. doi: 10.1094/MPMI-21-10-1371

Vahabi, K., Sherameti, I., Bakshi, M., Mrozinska, A., Ludwig, A., and Oelmüller, R. (2015). Microarray analyses during early and later stages of the Arabidopsis/Piriformospora indica interaction. Genom. Data 6, 16-18. doi: 10.1016/j.gdata.2015.07.019

Van Wees, S. C. M., Van der Ent, S., and Pieterse, C. M. J. (2008). Plant immune responses triggered by beneficial microbes. Curr. Opin. Plant Biol. 11, 443-448. doi: 10.1016/j.pbi.2008.05.005

Varma, A., Bajaj, R., Agarwal, A., Asthana, S., Rajpal, K., Das, A., et al. (2013). Memoirs of 'Rootonic'-the Magic Fungus. Noida: Amity University Press.

Varma, A., Bakshi, M., Lou, B., Anton, H., and Oelmüller, R. (2012b). Piriformospora indica: a novel plant growth-promoting mycorrhizal fungus. Agric. Res. 1, 117-131. doi: 10.1007/s40003-012-0019-5

Varma, A., Rai, M. K., and Sahay, N. S. (2000). "Microbial biotechnology: new paradigms and role in sustainable agriculture," in Microbialbiotechnology for Sustainable Development and Productivity, ed. R. C. Rajak (Jodhpur: Scientific Publishers), 22-37.

Varma, A., Sherameti, I., Tripathi, S., Prasad, R., Das, A., et al. (2012a). "The symbiotic fungus Piriformospora indica: review," in Fungal Association The Mycota IX, ed. B. Hock (Berlin: Springer-Verlag), 231-254. 
Varma, A., Singh, A., Sudha, M., Sahay, N. S., Sharma, J., Roy, A., et al. (2001). "Piriformospora indica: a cultivable mycorrhiza-like endosymbiotic fungus," in The Mycota IX, ed. B. Hock (Berlin: Springer-Verlag), $125-150$.

Varma, A., Sree, K. S., Arora, M., Bajaj, R., Prasad, R., and Kharkwal, A. C. (2014). Functions of novel symbiotic fungus - Piriformospora indica. Proc. Indian Natl. Sci. Acad. 80, 429-441. doi: 10.1371/journal.pone.0084920

Varma, A., Verma, S., Sudah, S. N., and Franken, P. (1999). Piriformospora indica, a cultivable plant growth-promoting root endophyte. Appl. Environ. Microbiol. $65,2741-2744$.

Waller, F., Achatz, B., Baltruschat, H., Fodor, J., Becker, K., Fischer, M., et al. (2005). The endophytic fungus Piriformospora indica reprograms barley to salt-stress tolerance, disease resistance, and higher yield. Proc. Natl. Acad. Sci. U.S.A. 102, 13386-13391. doi: 10.1073/pnas.0504423102

Waller, F., Mukherjee, K., Deshmukh, S. D., Achatz, B., Sharma, M., Schäfer, P., et al. (2008). Systemic and local modulation of plant responses by Piriformospora indica and related Sebacinales species. J. Plant Physiol. 165, 60-70. doi: 10.1016/j.jplph.2007.05.017

Wang, D., Weaver, N. D., Kesarwani, M., and Dong, X. (2005). Induction of protein secretory pathway is required for systemic acquired resistance. Science 308, 1036-1040. doi: 10.1126/science.1108791

Weiss, M., Selosse, M. A., Rexer, K. H., Urban, A., and Oberwinkler, F. (2004). Sebacinales: a hitherto overlooked cosm of heterobasidiomycetes with a broad mycorrhizal potential. Mycol. Res. 108, 1003-1010. doi: $10.1017 /$ S0953756204000772

White, J. F., and Torres, M. S. (2010). Is plant endophyte-mediated defensive mutualism the result of oxidative stress protection? Physiol. Plant. 138, 440-446. doi: 10.1111/j.1399-3054.2009.01332.x

Wittstock, U., and Halkier, B. A. (2002). Glucosinolate research in the Arabidopsis era. Trend Plant Sci. 7, 263-270. doi: 10.1016/S1360-1385(02)02273-2

Xu, G., Fan, X., and Miller, A. J. (2012). Plant nitrogen assimilation and use efficiency. Annu. Rev. Plant Biol. 63, 153-182. doi: 10.1146/annurev-arplant042811-105532

Yadav, V., Kumar, M., Deep, D. K., Kumar, H., Sharma, R., Tripathi, T., et al. (2010). A phosphate transporter from the root endophytic fungus Piriformospora indica plays a role in phosphate transport to the host plant. J. Biol. Chem. 285, 26532-26544. doi: 10.1074/jbc.M110.111021

Zarea, M. J., Chordia, P., and Varma, A. (2013). Piriformospora indica versus salt stress. Soil Biol. 33, 263-281. doi: 10.1007/978-3-642-33802-1_16

Zarea, M. J., Hajinia, S., Karimi, N., Goltapeh, E. M., Rejali, F., and Varma, A. (2012). Effect of Piriformospora indica and Azospirillum strains from saline or non-saline soil on mitigation of the effects of NaCl. Soil Biol. Biochem. 45, 139-146. doi: 10.1016/j.soilbio.2011.11.006

Zhang, W. Y., Wang, A. A., Hao, R. C., and Yang, T. (2014). Eendophytic fungus Piriformospora indica promotes growth and confers drought tolerance in sesame (Sesamum indicum L.). Chinese J. Oil Crop Sci. 1:11.

Zipfel, C., Kunze, G., Chinchilla, D., Caniard, A., Jones, J. D., Boller, T., et al. (2006). Perception of the bacterial PAMP EF-Tu by the receptor EFR restricts Agrobacterium-mediated transformation. Cell 125, 749-760. doi: 10.1016/j.cell.2006.03.037

Zuccaro, A., Basiewicz, M., Zurawska, M., Biedenkopf, D., and Kogel, K. H. (2009). Karyotype analysis, genome organization, and stable genetic transformation of the root colonizing fungus Piriformospora indica. Fungal Genet. Biol. 46, 543-550. doi: 10.1016/j.fgb.2009.03.009

Zuccaro, A., Lahrmann, U., Güldener, U., Langen, G., Pfiffi, S., Biedenkopf, D., et al. (2011). Endophytic life strategies decoded by genome and transcriptome analyses of the mutualistic root symbiont Piriformospora indica. PLoS Pathogens 7:e1002290. doi: 10.1371/journal.ppat.1002290

Conflict of Interest Statement: The authors declare that the research was conducted in the absence of any commercial or financial relationships that could be construed as a potential conflict of interest.

Copyright (C) 2016 Gill, Gill, Trivedi, Anjum, Sharma, Ansari, Ansari, Johri, Prasad, Pereira, Varma and Tuteja. This is an open-access article distributed under the terms of the Creative Commons Attribution License (CC BY). The use, distribution or reproduction in other forums is permitted, provided the original author(s) or licensor are credited and that the original publication in this journal is cited, in accordance with accepted academic practice. No use, distribution or reproduction is permitted which does not comply with these terms. 